\title{
The Organization of the Islamic Cooperation and the Conflict in Southern Thailand
}

\author{
By \\ Paoyee Waesahmae
}

\begin{abstract}
A Thesis
Submitted to the Victoria University of Wellington in Partial Fulfilment of the Requirements for the Degree of Master of International Relations (MIR)
\end{abstract}

School of History, Philosophy, Political Science and International Relations

Victoria University of Wellington

2012 


\begin{abstract}
The current wave of insurgency in the southern provinces of Thailand, where the majority of population are Muslim, sparked up in 2004 but shows no sign of ending in the near future. The insurgency caused by the conflict in the region which, along the time, has risen and fallen depending on surrounding circumstances. Given the scale and intensity of the conflict, it has increasingly attracted the attention of the outside world especially the Islamic world since the conflict is believed to be connected with religious elements. Despite of this, no specific Islamic countries have played a direct role in intervention in the conflict. The only intervention involved in the conflict was carried out by the OIC, a representative of 57 Islamic countries.
\end{abstract}

This essay attempts to examine the intervention of the OIC into the conflict in the southern provinces of Thailand in the name of Islamic countries in order to protect the rights of Muslim minorities as it claims and will explore the consequences of the tension between the OICôs mission to uphold these rights and sovereign states. 


\section{Table of Contents}

Introductioné é é é é é é é é é é é é é é é é é é é é é é é é é é é é é ....1

Chapter I: The Organization of the Islamic Cooperation (OIC)é é é é é é é é é é é é 4 Overviewé é é é é é é é é é é é é é é é é é é ..é é é é é é é é ......eé 4 The OICôs Charteré é é é é é é é é é é é é é é é é é é é é é é é é é ..6 OIC Ten Year Programme of Actioné é é é é é é é é é é é é é é é é é é 8 The OIC and the Concept of Ummahé é é é é é é é é é é é é é é é é é é 9 Ummahé é é é é é é ..é é é é é é é é é é é é é é ..é é é é é é é é .11 Ummah in Political Contexté é é é é é é é é é é é é é é é é é é é é é 13 The Implication of the Concept of Ummahé é é é é é é é é é é é é é é .é 13 The OIC and the issue of State Sovereigntyé é é é é é é é é é é é é é é é 15 The OIC and Muslim Minoritiesé é é é é é é é é é é é é é é é é é é é ..16 The OIC and the Conflict in the Philippinesé é é é é é é é é é é é é é é.. .20

Chapter II: Southern Thailand Conflicté é é é é é é é é é é é é é é é é é é é é 23 Historical Background, Separatist Movements and the Nature of Conflicté é é .é 23 Historical Background of Patanié é é é é é é é é é é é é é é é é é é é ..24 Patani Pre-annexationé é é é é é é é é é é é é é é é é é é é é é é é ...24 The Annexation of Patani into Thailandé é é é é é é é é é é é é é é é é ..26 Nationalism Under Field Marshall Phipulsongkramé é é é é é é é é é é é ....27

Divide and Ruleé é é é é é é é é é é é é é é é é é é é é é é é é é ....29

Historical Grievances: Anglo-Siamese Treatyé é é é é é é é é é é é é é é 30 Thai Nation Buildingé é é é é é é é é é é é é é é é é é é é é é é é é 30 Malay Muslim Separatist Movementsé é é é é é é é é é é é é é é é é é .29 GAMPAR: The First Movement Post-annexation Eraé é é é é é é é é é ...é .31 Haji Sulong and the Struggle Against the Thai Authoritiesé é é é é é é é é .é 32 Haji Sulongôs Seven Demandsé é é é é é é é é é é é é é é é é é é é é 33 The Emergence of Armed Movementsé é é é é é é é é é é é é é é é é ....34 Barisan Nasional Pembebasan Patani (BNPP)é é é é é é é é é é é é é é é .35 The Patani United Liberation Front (PULO)é é é é é é é é é é é é é é ...é 34 Barisan Revolusi Nasional (BRN)é é é é é é é é é é é é é é é é é ...é é 36 Current Wave and Trend of the Conflicté é é é é é é é é é é é é é é é ..é 37 
The Shifting Nature of the Conflicté é é é é é é é é é é é é é é é é é é 38

Chapter III: Thailand and the OICé é é é é é é é é é é é é é é é é é é é é é ...41

The Relationship Between Thailand and the OICé é é é é é é é é é é é é é 41

The Relationship Between the OIC and Separatist Groupsé é é é é é é é é é .43

Thailand and Observer Status of the OICé é é é é é é é é é é é é é é é é 45

The Secretary General and the Southern Unresté é é é é é é é é é é é é .é 46

Tak Bai Incidenté é é é é é é é é é é é é é é é é é é é é é é é é é ...46

The OIC Views of the Unrest in Thailandé é é é é é é é é é é é é é é ...é 48

What Are the Concerns of the Thai Authorities?........................................................51

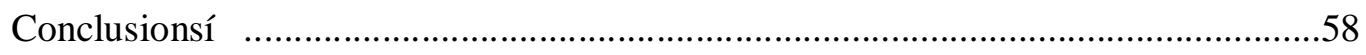




\section{Introduction}

The conflict in southern Thailand shows no sign of ending. The unrest occurs on a daily basis and is considered as a political and security dilemma for the Thai authorities, throughout the times. Until recently, the conflict seems gradually to have attracted the attention of the international community especially the Islamic world, although in past time the attention was limited in the region despite of the scale and intensity of unrest and the number of casualties. The conflict, to some extent, has been related to cultural and a religious cause has therefore caused some Islamic countries to draw their attention to the conflict. Among religious based organizations that pay very much attention to the conflict is the Organization of Islamic Cooperation (OIC), a group representative of 57 Islamic states. The OICôs intervention in the southern Thailand conflict is based on its mandate for the protection and upholding of the Muslimôs rights in the region. To the OIC, it is a combined mandate of promoting those rights in consistent with universal human and civil rights internationally, and the endeavour of upholding the cause of the global Islamic Ummah as enshrined by Islam. However, the promotion of human rights internationally, or in the context of a western understanding may posit some common understanding with that of Islam. But given the deepest meaning of promoting rights in the name of the Islamic Ummah, with a religious bond, such promotion may be different in terms of how it is managed.

However, in spite of relative agreement that the promotion of human rights is highly important to the extent that some countries or organizations are willing to intervene in the othersôaffairs, the effectiveness of such intervention will be in doubt when the promotion of human rights is brought into conflict with the interests of sovereign states. In the contemporary world, it is quite common to our understanding that the sovereign state is not only the central power in shaping international political trends. Many factors tend to emerge and overshadow the essence of state sovereignty to the extent that the classical notion of state sovereignty might have to be rethought.

This essay will look at OIC involvement in the conflict in Southern Thailand to understand how the tensions between state sovereignty and the promotion of universal values are managed in the Islamic world. As a transnational organization, the OIC was established, at the outset, as a forum to unify the Islamic states from over all continents to denounce the incident of arson attack on a mosque in Morocco, it then has gradually grown up to become the largest Islamic organization with a political motivation, comprised of 57 Islamic 
sovereign states. The establishment of the Department of Muslim Minorities and Communities in the OIC is an evidence of the OICôs attachment to the importance of Muslim minorities elsewhere in non-member states. It is also considered to be the OICôs instrument in carrying out its mandate in upholding, safeguarding and protecting the rights of Muslim minorities, around the globe, as the OICôs Charter emphasizes. As a result, the OIC will always emerge wherever the case of Muslim minorities has risen to its concern, especially when the OIC perceives that the rights of Muslim minorities in certain parts of the world are being abused or ill-treated by their host country.

With the global concept of Ummah the OIC, as the largest religious based organization will continue to struggle in promoting the rights of Muslim minorities in non-member states. But the contention between state sovereignty and universal values will be an obstacle for the OIC in carrying out its mission. As a representative of its member states, the OIC is not totally free from its members. Any decision that could undermine the good existing relationship between sovereign states would be more likely opposed by member states. Such phenomenon does not totally indicate the failure of the OIC in promoting human rights, but it implies some realities that when the interests of sovereign states are at stake, it may cause some difficulties for the OIC in carrying out its mandate. In terms of the conflict in the southern provinces of Thailand, the OIC might have some influence in putting pressure on the Thai authorities but Thailand will overtake the issue by relying on its allies within the OIC in order to counter the OICôs actions.

There is a wide range of academic literature about human rights promotion by international organizations in a Western framework. However, much less is available about non-Western organizations, or specifically in the context of Islamic organization. This thesis will look at the OICôs attempts to promote human rights for Muslim through a case study of the OICôs involvement in attempts to resolve the on-going conflict in Southern Thailand.

This essay will be divided into three parts. The first part will be about the introduction of the OIC. I will further examine the concept of Islamic Ummah as a framework of the OIC in its endeavours in promoting the cause of Muslims, throughout the world. In this chapter, I will talk about the OIC and Muslim minorities with a very brief story of its intervention in the Philippines conflict. By understanding the concept of Ummah in various contexts I will then conclude the chapter by some clarification as to why and how the OIC tends to promote the Muslimôs rights in non-Islamic states. The second part of this essay will be about an overview 
of the southern Thailand conflict. In doing so, I will trace back the historical background of the conflict by looking at the historical background of the region so as to understand why the conflict has occurred. As a part of this chapter, I will briefly touch on the overall evolution of the conflict with some information on separatist movements in the region, to gain a better understanding of the conflict. The last chapter of this essay will talk about the OIC and its intervention in the conflict. This chapter will involve mostly the main part of the essay which discusses how the OIC has intervened in the southern Thailand conflict. In doing so, this part will draw a picture of the overall relationship between Thailand and the OIC, and some of the obstacles and difficulties that stand on the way of this relationship. This part will then end with some indication of the outcome of the tension between missions upholding universal rights by inter-governmental bodies with sovereign states. Towards the end of this chapter, I will then discuss the sorts of difficulties the OIC faces and what are the consequences of the contention between the OIC, on one side, and Thailand with its allies in the OIC, on the other. 


\section{Chapter I:}

\section{The Organization of the Islamic Cooperation (OIC) ${ }^{1}$}

This chapter introduces the OIC as it is the main objective of the essay. It is quite common to say that the OIC is considered to be the largest international organization related to religious element. Historical background of the establishment of the OIC will reflect the nature of the organization. Over time, the OIC has developed, and still develops, itself to meet challenges. The OICôs scope of work is not limited within its member states. One of the main mission carries out by the OIC is to protect the rights of Muslim minorities in non-Islamic states.

I begin this chapter with an overview of what the OIC is and where it came from. Then I go on to look at the idea of the global Ummah, and the notion of Ummah in different dimensions. I will then shed light on the tension between the idea of Ummah and the classic notion of a sovereign state.

In terms of the OICôs work to promote the right of Muslim minorities, I will briefly look at the case of the OICôs intervention in the Philippines conflict as the OIC would always consider the case as its best practice to apply to the conflict in the south of Thailand.

\section{The Organization of the Islamic Cooperation (OIC): an overview}

On 25 September 1969, after an incident of arson attack on Al-Aqsa mosque in Jerusalem, Arab leaders gathered in Rabat, Kingdom of Morocco, to discuss the situation ${ }^{2}$. The gathering is thought to have been the first Islamic Summit, with political motivations in the current history of Islamic politics. The summit, attended by Arab and Islamic leaders, was initially aimed to discuss merely the issue of arson attack on Al-Aqsa mosque with no agenda beyond that incident. However, eventually it concluded, after a long debate from participants, by addressing wider issues of the Arab-Israeli conflict, rather than merely the issue of a single arson attack, and even further, the meeting was considered as the first step in the establishment of the OIC. ${ }^{3}$ The summit is thus considered to be the historical summit

\footnotetext{
${ }^{1}$ Formerly known as ñThe Organization of the Islamic Conferenceò. The change of the organizationôs name was approved by its 57 members at the $38^{\text {th }}$ session of the council of foreign ministers (CFM) meeting held in Astana, Kazakhstan, on 28 June 2011. See www.oic-oic.org for details.

${ }^{2}$ Official website of the OIC: www.oic-oci.org

${ }^{3}$ Ekmeleddin Ihsanoglu, The Islamic World in the New Century: the Organization of the Islamic Conference, 1969-2009, Hurst, 2009. 25
} 
concluded by the decision of Arab leaders to establish the Organization of the Islamic Conference.

Currently comprising of 57 countries, the OIC is considered to be the second largest intergovernmental organization after the United Nations and the largest organization related to religious motivation ${ }^{4}$. Moreover, there are more than twenty observers from sovereign states, non-sovereign states and organizations that attend OIC meetings. Although the OIC, by its name and through its functioning, is relatively a religious body but its Charter also lies upon the modern concept of the sovereign nation-state system, as I will discuss later on.

The main organ of the OIC is the Conference of Foreign Ministers (CFM) which convenes annually to discuss critical issues challenging the Islamic world. The most important mechanism of the OIC in shaping the path for the OIC to proceed is the OIC Summit which is a gathering of head of states every three years with, sometime, an extraordinary session if the OIC deems it necessary. There is also another important affiliated body within the OIC namely Committee for Economic and Trade Cooperation (COMEC), International Islamic News Agency (IINA) which was established in 1972, the Islamic Development Bank (IDB) and the Islamic Solidarity Fund. Bureaucratically, with its headquarter in Jeddah, Saudi Arabia $^{5}$, the OIC Secretariat is the functional administrative and financial centre. Another important element of the OIC is a contact group with various specific mandates supervised by an expert group in related fields.

Like any other inter-governmental organization the members are comprised of a core influential countries that play a very significant role within the organization, and others that play the role of followers. The said influence exerted by the core members may constitute various forms such as financial contribution and the eminence of roles in which certain countries have in their particular region. It is therefore quite common to say that the OIC comprises some power elites within the organization and some ordinary states which still lack negotiating power and have less opportunities to contribute to some critical decisions. The organization also has several observers with different categories including Thailand. It could be said that the OIC in its functioning, like most of the trans-national organizations, faces challenges both from within and from the outside. Being a large organization comprised of several countries of very different backgrounds with varieties of interests is the biggest

\footnotetext{
${ }^{4}$ Ciljar Harders and Metteo Legrenzi, Regionalism? Regional Cooperation, Regionalism and Regionalization in the Middle East. Ashgate, England, 2008. 126

${ }^{5}$ Ibid. p 126
} 
challenge for the organization. Furthermore, the organization is sometimes in a very critical situation in maintaining its position while dealing with sovereign states. Moreover, the work of the OIC will definitely be involved in controversy when it deals with non-state members. The question will not be extremely serious if the OIC attempts to intervene in its own member statesô affairs. But when it deals with non-member states or non-Islamic states debates and reactions emerge.

Recently, the OIC has been targeted for lack of effectiveness in addressing various critical issues in the Islamic world. ${ }^{6}$ When political tensions in the Islamic world are raised to its peak the states tend to be negligent in solving their problems by referring to the OICôs mechanism ${ }^{7}$. In spite of this, the OIC is relatively important to its members as it is the only organization that is able to unite all Islamic countries under the same roof.

\section{The OIC's Charter}

In order to gain a clearer picture of the OIC it is quite useful to shed the light on the OICôs Charter which is considered as the backbone of the organization and through the charter the OIC carries out its mission in pursuit of the goals as proposed.

The OICô Charter comprises of: ${ }^{8}$

- Enhance and consolidate the bonds of fraternity and solidarity among the Member States;

- Safeguard and protect the common interests and support the legitimate causes of the Member States and coordinate and unify the efforts of the Member States in view of the challenges faced by the Islamic world in particular and the international community in general;

- Respect the right of self-determination and non-interference in the domestic affairs and to respect sovereignty, independence and territorial integrity of each Member State;

- Ensure active participation of the Member States in the global political, economic and social decision-making processes to secure their common interests;

\footnotetext{
${ }^{6}$ Shahram Akbarzadeh and Samina Yasmeen, Islam and the West: Reflection from Australia, University of New South Wales Press, 2005. 6

${ }^{7}$ Ibid. 6

${ }^{8}$ From the official website of the OIC, accessed on May 2012. http://www.oic-oci.org/page_detail.asp?p_id=52
} 
- Reaffirm its support for the rights of peoples as stipulated in the UN Charter and international law;

- Strengthen intra-Islamic economic and trade cooperation; in order to achieve economic integration leading to the establishment of an Islamic Common Market;

- Exert efforts to achieve sustainable and comprehensive human development and economic well-being in Member States;

- Protect and defend the true image of Islam, to combat defamation of Islam and encourage dialogue among civilizations and religions;

- Enhance and develop science and technology and encourage research and cooperation among Member States in these fields;

In order to realize these objectives, Member States shall act, inter alia, in accordance with the following principles:

- All Member States commit themselves to the purposes and principles of the United Nations Charter;

- Member States are sovereign, independent and equal in rights and obligations;

- All Member States shall settle their disputes through peaceful means and refrain from use or threat of use of force in their relations;

- All Member States undertake to respect national sovereignty, independence and territorial integrity of other Member States and shall refrain from interfering in the internal affairs of others;

- Member States shall uphold and promote, at the national and international levels, good governance, democracy, human rights and fundamental freedoms, and the rule of law.

From the above passage, it could be seen as evidence that the OIC, in its functioning, lies not only on the classical concept of ñUmmahòbut also adhere to the notion of modern concept of international organization as well as to the understanding of a universal notion of state sovereignty. From close scrutiny, it could be found that while the OIC talks about consolidating the bonds of fraternity and solidarity among the Member States, the Islamic states, and safeguarding, supporting legitimate causes of its members in view of the challenges faced by the Islamic World, the OIC attaches importance to being a good member 
of the world community and respectful of the sovereignty, integrity and dignity of states. The OIC therefore is an organization that combines religious elements with universal characteristics of the organization.

Recently, under the administration of Professor Ekmeleddin Ihsanoglu, ${ }^{9}$ the OIC has carried out many reforms in order to strengthen its performance and to be able to cope with challenges facing the Muslim world in the $21^{\text {st }}$ Century. After assuming office as the $9^{\text {th }}$ Secretary General of the OIC, Professor Ihsanoglu reviewed the Charter and carried out several essential reforms and initiatives in attempt to increase the efficiency and effectiveness of the OIC. The most remarkable reform was the adoption of ñThe Ten-Year Programme of Action. $^{10}$ The programme is a significant blue print of the current work of the OIC. Furthermore, it is an impetus to its member states to work along with the OIC, after more than a decade of disappearing from the worldôs political arena. ${ }^{11}$

\section{OIC Ten Year Programme of Action}

In 2005, Islamic heads of states gathered in Makkah, Saudi Arabia, for an extra-ordinary summit called by King Abdullah bin Abdulaziz Al-Saud of Saudi Arabia to discuss the proposed plan of action initiated by King Abdullah to face the challenges of the $21^{\text {st }}$ century. The Summit concluded by adopting the OIC Ten Year Plan of Action based on the views and recommendations of Muslims scholars and intellectuals, convinced of the potential for the Muslim Ummah to achieve its renaissance, and in order to take practical and effective steps towards strengthening the bonds of Islamic solidarity, achieve unity of rank, and project the true image and noble values of Islam to the outside world. The Ten-Year program of Action reviews the most prominent challenges facing the Muslim world today, as well as ways and means to address them in an objective and realistic manner in order to serve as a practicable and workable program for all OIC member states. The Program clearly stated that it aims to reach the full potential of the Islamic Ummah and calls for its renaissance.

\footnotetext{
9 Ekmeleddin Ihsanoglu, a Turkish Academician and Diplomat, is the ninth Secretary General of the Organization of Islamic Cooperation (OIC). As the first ñdemocratically electedò Secretary General of the OIC, Ihsanoglu took office in January 2005. He earned his Bachelor of Science degree from Ain Shams University in 1966, and Masterôs degree in chemistry in 1970 from Al-Azhar University. After completing his Ph.D. studies at Ankara University, Turkey in 1974, he did his post-doctoral research from 1975 to 1977 as a research fellow at University of Exeter, the United Kingdom. Source: official website of the OIC, accessed on May 2012. http://www.oic-oci.org/page_detail.asp?p_id=58

${ }^{10}$ Jan Aart Scholte, Building Global Democracy?: Civil Society and Accountable Global Governance, Cambridge University Press, 2011, 152.

${ }^{11}$ Official website of the OIC, accessed on May 2012. http://www.oic-oci.org/page_detail.asp?p_id=58
} 
In terms of protecting the human rights within the OIC member states and in non-Muslim states, the OIC reflect the importance of such mission in the said program as well. The Program is designed to aim at ensuring the protection of human and minoritiesô rights in those states as equal to those of its members. To gain such goals, the head of states agreed as follows: ${ }^{12}$

- Seriously endeavour to enlarge the scope of political participation, ensure equality, civil liberties and social justice and to promote transparency and accountability, and eliminate corruption in the OIC Member States;

- Call upon the Islamic Conference of Foreign Ministers to consider the possibility of establishing an independent permanent body to promote human rights in the Member States, in accordance with the provisions of the Cairo Declaration on Human Rights in Islam and to also call for the elaboration of an OIC Charter for Human Rights.

Introduce changes to national laws and regulations in order to guarantee the respect of human rights in Member States;

- Mandate the OIC General Secretariat to cooperate with other international and regional organizations to guarantee the rights of Muslim Minorities and Communities in non-OIC Member States, and promote close cooperation with the Governments of the States hosting Muslim communities.

As the OICôs Charter clearly states, one of the main mission of the OIC is to achieve certain goals for the benefit of the ñUmmahò. It is therefore quite important to understand what does the ñUmmahò mean? It is understandable that the notion of ñUmmahò is relatively important to the OIC in its functioning given that the word ñUmmahò is widely used within the OIC in particular and the Islamic world in general. It is undoubted, again, that the word ñUmmahò might be used by different group of people or institutions to gain different goals. Finally, if the notion of Ummah is understood as a community that is bound together by religious faith, which is Islam, it is clear then what the OIC struggles to do.

\section{The OIC and the Concept of Ummah}

As the largest Islamic inter-governmental organization, the OIC endeavours to work for the interest of its 57 member states, spread over four continents. The OIC is the second largest

${ }^{12}$ Official website of the OIC: www.oic-oci.org 
inter-governmental organization after the United Nations. After the collapse of the Caliphate $^{13}$, the first system of governance known in the history of the Islamic world, the OIC seems to be the only Islamic organization that works, with political motivation, to unify Islamic states under the concept of Islamic ñUmmahò The following passage attempts to explore the important of ñUmmahò as a notion in a political context. By understanding the concept of ñUmmahò we might gain a clear picture of how the OIC works, especially in terms of the OICôs involvement in the conflict in southern Thailand, in particular, and in nonIslamic states, in general. In terms of the relationship between Thailand and the OIC, what is thought to be the most prevailing reason, beside the commitment of Thailand as an observer member in the OIC, is OICôs framework in carrying out its mission by adhering to the concept of Ummah, to preserve and protect the interest of Muslim communities.

After the abolition of the Ottoman Caliphate in 1924 several attempts were undertaken by Islamic states as well as religious institutions to convene a Muslim congress, aimed at restoring a renewed Caliphate able to address various issues challenging the Islamic world. To name some: the ñCairo Congressò held by prominent Egyptian religious figures and attended by representatives from Arab and Islamic countries. Although the Congress did not succeed in establishing a new Caliphate or an organization but it was considered as a remarkable turning point in contemporary Islamic history by injecting impetus into the Islamic world and underlining the importance of having an alternative to the Caliphate. Consequently, the Mecca Conference held in 1926 was another significant Islamic gathering at which the Congress of Islamic World was formed. In 1931, the General Islamic Congress in Jerusalem was held which was more political. The Congress was initiated by the Grand Mufti of Palestine and President of the Supreme Muslim Council of Palestine, at the time, AlHaj Amin Al-Husseini. The Congress aimed at deliberating upon the affairs of Muslims and sought to defend the interests of the Ummah ${ }^{14}$ as they perceived that they were obliged to do so by religious commands.

To understand such phenomenon, the concept of Ummah must be brought into attention. The core question here is that to what extent, if there is any, the concept of Ummah influences the work of the OIC? How the OIC will maintain a balance between what it claims, as stated in

\footnotetext{
${ }^{13}$ The caliphate period (632-1258) started directly after the Death of Prophet Muhammad. It could be divided into three significant phases: the Right Guided Caliphs (632-661), the Ummayad dynasty (661-750) and the Abbasid caliphs (750-1258). Source: John L. Esposito, Islam and Politics, Syracuse, New York, 1984, 7

${ }^{14}$ Prof. Ekmeleddin Ihsanoglu, the Islamic World in the New Century. Hurst, p13-22
} 
its Charter, of enhancing and strengthening the bonds of unity and solidarity while respecting national sovereignty, and its interference in other countriesôaffairs in the name of Ummah.

In recent days, the concept of Ummah is often heard in various occasions, throughout the globe. Nevertheless, the actual meaning of the concept is still widely debated among scholars $^{15}$. The concept, to some extent, is used to legitimize the means of gaining some political goals, by certain groups of people. Interestingly, the concept could be considered as a non-state actor that challenges the modern understanding of state sovereignty within international relations. Until recently, the overall picture of the Islamic world, in the eyes of the outside world, is relatively weak and scattered due to political uncertainties in many Islamic states around the world. But the notion of Islamic Ummah is, undoubtedly, still alive, regardless of the individual weakness of Islamic nations.

\section{"Ummah"}

To understand the concept of Ummah, it would be useful to trace back to the word ñUmmahò and what it indicates in terms of its linguistic meaning and the relevant meaning in the political sphere. There is no precise formula to interpret the word ñUmmahò into its exact meaning in everyday life due to the fact that it expresses a variety of realities ${ }^{16}$. Furthermore, the Quranic verses in which the word appears are subject to exegesis: therefore, there is always more than one explanation which can be drawn. The word ñUmmahò is thought to be originally from the Hebrew, meaning ñMotherò, known before the emergence of the Islamic era. Statistically, the word ñUmmahò is cited in the Holy Quran 62 times $^{17}$. According to Ejaz Akram, the word ñUmmahò was developed to understand according to its concept, from being understood as its superficial meaning. In the holy book of Al-Quran, the word Ummah is used to indicate a small group of people in ñMedinaò or the ñMadinanò period of the Prophet Muhammadôs life. This could be evident from the text of the ñConstitution of Medinaò $^{18}$ as summarized by Frederick M. Denny ${ }^{19}$, from its 47 articles found that the term ñUmmahò in the first article is used to indicate Believers (in Arabic, mu'minun). In article 25

\footnotetext{
${ }^{15}$ Marranci Gabriele, The Anthropology of Islam. Oxford: Berg, 2008. 107-111

${ }^{16}$ Frederick M. Denny, The Meaning of Ummah in the Quran, History of Religion 15 (1975): 34-70, University of Virginia

${ }^{17}$ Ejaz Akram, Muslim Ummah and its Link with Transnational Muslim Politics, Islamic Research Institute, International Islamic University, Islamabad. Islamic Studies, Vol 46 No. 3 (Autumn 2007), pp. 381-415. p 383

${ }^{18}$ Some authors prefer to write ñMadinahò instead of ñMedinahò. I tend to prefer the word ñMadinahò since the original Arabic pronunciation of the word is relatively consistent.

${ }^{19}$ Frederick M. Denny, Ummah in the Constitution of Medina, Journal of Near Eastern Studies, Vo. 36. No. 1 (Jan. 1977) p.p. 39-47
} 
it is used to refer to the Jews. The term ñUmmahò at the time, therefore, was used to indicate not only Muslims as members of a certain community but also to refer to Jews, and Christians who resided in Madinah. The word ñUmmahò therefore, according to the said hypothesis was not limited to Muslims but to include also other faiths within the same community.

However, what the word ñUmmahò implies is something deeper than its superficial meaning. The best evidence of this implication could be found in both the Quran and Hadith which are considered as constitutional references in Islam. The Quranic verse 21:92 exhorts: ñVerily, this brotherhood (Ummah) of yours is a single Brotherhood (In Arabic, Ummatan Wahidatan), and I am your Lord and Cherisher: therefore Serve Me (and no other)ò. According to $\mathrm{Ejaz}^{20}$, this verse of the Quran posits a direct statement leaving no doubt about the importance of Ummah, as one community, in the minds of Muslims. ${ }^{21}$ Beside the Quran, the importance of Ummah is described in the Hadith literature as well. The Prophet said: ñEveryone in my Ummah will enter the Garden (Paradise) except the one who rejects meò. According to Muhammad Iqbal, all political action is the expression of Islamic spirituality. ${ }^{22}$ By this, it could be simply understood that those who reject Islam are not considered members of Islamic Ummah.

Upon closer examination of the meaning of ñUmmahò as ascribed in the Quran it would be found that ñUmmahò is also used to indicate the Muslim community as a whole regardless of states or nations. In general, the Islamic transnational community which relates to religion is known as ñUmmahò, predates the emergence of centralized secular states. ${ }^{23}$ The Quranic verse exhorts ñYou (Muslims) are the best nation brought out for Mankind, commanding what is righteous (Ma'ruf) and forbidding what is wrong (Munkar) 3:110ò In this context, it is clear that the Quran addresses the whole nation of Muslims as Ummah, a unified community bound with Islamic brotherhood and the same faith. It is then beyond the conventional boundaries known within modern international politics.

Furthermore, according to some Islamic scholars, the concept of Ummah is not perceived merely by its superficial meaning which ascribes only a social sense of engagement among the Muslim population. Instead, the concept of Ummah according to them must be bound by

\footnotetext{
${ }^{20}$ Ejaz Akram, Muslim Ummah and its Link with Transnational Muslim Politics, p 383

${ }^{21}$ Ibid, p. 384

${ }^{22}$ Cited by Ejaz Akram in ibid, p. 386

${ }^{23}$ Jeff Haynes, Transnational Religious Actors and International Politics, Third World Quarterly, Vol. 22, No. 2 (Apr., 2001) p. 145
} 
several dimensions, especially religious dimensions, by which Muslims, in personal and collective levels are bound together.

\section{Ummah in political context}

M.A. Shaban, in his book, argued that ñUmmahò is a political concept rather than religious ${ }^{24}$. The main reason for such a debate can be traced back to the historical narration of the ñMadinah Peace Concordò which was agreed by both Muslims and Jews who resided in Madinah to defend the city from outside offensives ${ }^{25}$. The term used in the said agreement was ñUmmahò. This included all Madinahôs people regardless of their religion. The word ñUmmahò hence used to indicate Muslims and Jews, without distinction. After the era of Muhammad, the Caliphate was established as successor in the Islamic political system. Linguistically, the word ñCaliphò means the óuccessorô In Islamic understanding the ñCaliphò was a representative of the prophet Muhammad. The caliphate is a symbol of Muslim unity.

While the concept of Ummah is always related to a religious understanding, one of the realities that could not be ignored is that, in some cases, religion could be used as instrumental to gain certain goals for certain groups of people.

\section{The implication of the Concept of Ummah}

It is said that Islam is the only religion that unifies the people on a religious basis. Within Islam, the concept of Ummah constitutes a very concrete concept of identity, bonding together people with the same sentiments beyond the scope of national or state identities. Superficially, by examining the OICôs charter which is considered as a main framework of the OIC it could be said that the OIC adheres to the notion of modern secularism in the international system. This is due to the fact that all historical narratives of Islamic states and nations found that people at the time bore allegiance in most cases, to their particular Kings and tribal leaders. This allegiance bound people together, rather than brotherhood or same faith. Until recently, there are 57 Islamic sovereign states over four continents as members of the OIC as well as a small number of states and organizations that hold the status of observer members, including Thailand. These states are quite different in terms of identities, ethnicities, languages and cultures. Furthermore, every single state has its very own interests

\footnotetext{
${ }^{24}$ M. A. Shaban, Islamic History: A New Interpretation I A.D. 600 ï 750 (A.H. 132), Cambridge University Press, 1976. 11

${ }^{25} \mathrm{Ibid}, 12$
} 
to pursue according to its national strategy. Nevertheless, the concept of Ummah, as perceived by these states is still static. ${ }^{26}$

It is widely believed, among Muslim seculars that a Muslim consciousness in the concept of Ummah brought about the establishment of the OIC. ${ }^{27}$ In fact, due to the spread of its usage on various occasions within the field of international relations, its precise meaning is still widely debated.

According to Sardar, the OIC has:

[the] ability to bring all the nations of the Muslim world, even those who have openly declared war on each other, under one roof, and to promote cooperation and communication between Muslim people that has not been possible in recent history. Moreover, it has the potential of becoming a powerful institution capable of articulating Muslim anger and aspiration with clarity and force...The creation of the OICé indicates that the movement of a return to Islamic roots is a transnational phenomenon. $^{28}$

From the above passage, it is suggested that the purpose of the OIC is to promote Islamic solidarity and enhance cooperation among member states in the social, cultural, scientific, political and economic fields. In fact, one of the many realities that cannot be denied is that Muslim people are divided into several sects by various doctrinal issues, notably between the Sunni and Shia in interpretations of the faith in different ways, however, notwithstanding that, the concept of ñUmmahò, is a transnational civil society.

One interesting feature of the concept of Ummah is the sense of brotherhood amongst Muslims regardless of nationalities, races or even some fragmentation between Sunni and Shia sects. Many Islamic thinkers assert that the sense of brotherhood is beyond any other boundaries. It is therefore quite common in the Islamic world to say the concept of fragmentation is unacceptable. One of the best evidence of the importance of brotherhood in

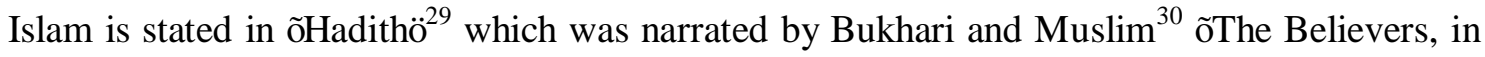
their mutual love, mercy and compassion, are like one body: if one organ complained, the rest

\footnotetext{
${ }^{26}$ Ali Muhammadi, Islam Encountering Globalization, New York, 2002. 182

${ }^{27}$ Abdullah Ahsan, Ummah or Nation? Identity Crisis in Muslim, Leicester: Islamic Foundation, 1992

${ }^{28}$ Z Sardar, Islamic Future. The Shape of Ideas to Come, London, Mansell, 1958. pp 51-52

${ }^{29}$ The term hadith (plural: hadith, hadiths, or alhadith) is a report attributed to the Prophet Muhammad, describing his words and actions and representing the chief source for knowing his authoritative precedent (Sunnah). Source: Jonathan A. C. Brown, Hadith, Oxford University Press, 2010. 3

${ }^{30}$ Bukhari and Muslim are two most highly respected and authenticated collections of Hadith in Islam
} 
of the body develops a feverò. According to Prof Ihsanoglu, the OIC represents the concrete manifestation of the concept of Islamic solidarity, Ummah, which is enshrined in the Holy Quran and the traditional sayings to the Prophet Muhammad, Hadith, in the contemporary world $^{31}$. To sum up, it could be understood from the above passage that the concept of Ummah is used to legitimate the OICôs intervention in other statesôaffairs. Such intervention might not be seriously debated if it happens within Islamic states who have committed themselves to the OIC by membership. But this is, definitely, not the case if it happens outside OICôs member states.

\section{The OIC and the issue of state sovereignty}

Among other issues that should be brought to attention when examining how the OIC works is how the OIC could maintain its position as a trans-national organization in dealing with its member states that possess sovereignty over their territories without undermining such sovereignty and the integrity of its member states. On the other hand, how would the states prioritize the issues they face? Finally, how such phenomena affects the OICôs endeavours.

It is undoubted that trans-national organizations emerged in the sphere of international relations as a new factor affecting statesôperformance, and seen as an unconventional factor. The issue is much more widely debated if such trans-national organizations are related to a religious dimension, like the OIC. According to Bealy, sovereignty is á claim to authority, originally by foreign monarchs, but by state since the Treaty of Westphalia in 1648. A state becomes sovereign when other states recognize it as such. ô $^{2}$ The classical notion of state sovereignty does not mention any other actor, except the state, a transnational religious factor therefore is modern and unconventional actors that play a role thus mobilizing statesôroles in the international political arena. Bealy argued that the reason of the absence of religious factors in explaining state sovereignty is acceptable given the history of the past 400 years in Western Europe. After the spread of Islam from its heartland, in the Arabian Peninsula, to other parts of the world, Islam as a religious, social and cultural system grew to become a global religion via the growth of a transnational religious community. In this context, the transnational religious community could also be understood as the global Islamic Ummah since, in Islam, its community is bounded by religious element regardless of conventional territorial boundaries.

\footnotetext{
${ }^{31}$ Ekmeleddin Ihsanoglu, The Islamic World in the New Century. p 13

${ }^{32}$ Cited by Jeff Heynes, Transnational Religious Actors and International Politics. Third World Quarterly, 22:2, $143-158$, p. 144
} 
As a transnational religious body, the OIC represents a forum for the Islamic states, in the name of Islam which, to some extent, exercises its legitimate power, as given by the Charter, and influences the state members in a very narrow and limited scope. In spite of the said power and influence, the OIC could not totally undermine states sovereignty due to the fact that its member states will still prioritize their national interests and other local considerations which have a very potential effect on local political stability. This could be evident by several contemporary issues that happened within the Islamic world, it is very few occasions that the OIC could really exert its power in solving the issues. Furthermore, state rivalries within the OIC is still exist and yet another element to be proved that state sovereignty and national interest are hardly undermined, even though the OIC, as a transnational religious body is considered a non-state actor that might have ability to influence member states. What can be witnessed from realities on the ground is that sovereign states that belong to the OIC tend to address issues individually without much attention to the organization. One might suggest that it is because of the ineffectiveness of the OIC in coping with critical issues that occurr within the Islamic States, but such phenomenon could also be evident that sovereign states prefer to manage their own affairs without interference from the organization for the best protection of statesôinterests.

\section{The OIC and Muslim Minorities}

Statistically, there are more than 500 million Muslims who reside in non-Muslim states ${ }^{33}$. These Muslim minorities constitute one third of the overall Muslim population in the world. Having considered the large number of Muslim minorities throughout the globe and the complexities of social, political and cultural dimensions that those Muslims may face the OIC therefore established a Department of Muslim Minorities and Communities. The Department is a platform for the OIC to address various issues of the Muslim minorities and communities. The establishment of the said department stresses the importance that the OIC attaches to Muslim minorities and communities in non-Muslim countries. Through the endeavours of the Department of Muslim Minorities and Communities the OIC interacts in Muslim Minoritiesô affairs in non-member states. The Department is an instrument for the OIC to reach out to the Muslim minorities in those countries and address their problems as it deems necessary.

\footnotetext{
${ }^{33}$ Ekmeleddin Ihsannoglu, The Islamic World in the New Century. p 127
} 
According to Talal Daus, a Director in the Department of the Muslim Minorities and Communities, the OIC addresses the issues of Muslim minorities throughout the world, over the years, through the following strategies ${ }^{34}$ :

- Keeping channels of contact with the Muslim minorities and assisting them to interact with the OIC member states and the OIC General Secretariat to learn about their needs, state of treatment extended by the state and extending them support and advice;

- Developing relations or direct contact with those countries having Muslim Minorities to underline the need to preserve their rights, through negotiation and engagement in constructive and diplomatic dialogue, in full consideration of the sovereignty and the territorial integrity of the concerned country;

- Assisting the Muslim minorities in their dialogue with their governments for assimilation and co-existence with other minorities

- Seeking cooperation from Islamic organization and institutions to cater for the economic and social needs of the Muslim minorities and communities.

Basically, the issues of minorities are politically considered as internal issues of the state that host any minority group. Practically, the issues of minorities are well spread beyond the territory where they exist, especially in the current era when the world has become a small village. As a result, the issues highly attract attention by some states that may have direct or indirect potential of interest to intervene. Recently, as it could be witnessed, not only states that are willing to interfere, for some reason, but non-state actors, to some extent, are also attracted and ready to oblige themselves to solve the issues.

At the outset of its establishment, the OIC was highly conscious not to interfere into any statesôaffairs when the issues of Muslim minorities were raised. The first Muslim minorityôs issue that was taught to be brought into the attention of the OIC was the issue of the Muslim minority in southern Philippines, Mindanao, which was one of the conferenceôs agenda during the third Ministerial Council of Foreign Ministersôconference which was held in 1972

\footnotetext{
${ }^{34}$ An oral note addressed by Talal Daus, Director in the Department of the Muslim Minorities and Communities of the OIC, at the $2^{\text {nd }}$ Session of the Forum on Minority Issues, Minorities and Effective Political Participation. 12-13 November 2009. Office of the United Nations High Commissioner for Human Rights (OHCHR). Accessed on April 2012. http://www2.ohchr.org/english/bodies/hrcouncil/minority/oral_statements_forum_minority_2009.htm
} 
in Jeddah, Saudi Arabia ${ }^{35}$. During the said conference, a report concerning the issue of Muslim minority in the Philippines was presented for discussion among participants. ${ }^{36}$ Furthermore, a wider issue of Muslim minorities elsewhere in the world was also seriously debated during the said conference. Meanwhile, the conference was attracted by a report concerning statistics of Muslim minorities in various non-member states and the various difficulties that they faced. As a result, the conference concluded the meeting by issuing a resolution about the Muslim minorities. The meeting concluded that Muslim minorities in some countries do not enjoy their religious and political rights as recognized by international law and practice. The OIC therefore called on countries that host Muslim minorities to respect their cultural and ethnical beliefs and faith in accordance with the Charter of the United Nations. ${ }^{37}$ From this point onward, the issues of Muslim minorities were always contained in the meeting of the OIC.

Dr. Sarawut Aree roughly categorized Muslim minorities throughout the world into 5 groups $^{38}$. First, Muslim minorities who reside within the territorial context of a certain state. This group of minorities is considered to be minorities within the state but they are majorities in their particular region such as Muslim minorities in Thailand and the Philippines. This group of minorities often struggle to secede themselves away from majorities in the same state, for certain reasons. Second, Muslim minorities who suffered from statesô policies, whether those policies were intentionally aimed at those minorities or unintentionally affected such as Muslim minorities in India. Third, Muslim minorities who migrated to reside in non-Muslim countries such as Muslim minorities in the USA, Europe and elsewhere. These groups of minorities are likely integrated with their fellow nations since their migrations were for the betterment of their lives. Fourth, Muslim minorities who were politically marginalized and often became victims of civil war in the countries where they reside. In some cases they were forced to take side, supporting either the authorities or rivals, such as Muslim minorities in Sri Lanka. Fifth, Muslim minorities whose populations are

\footnotetext{
${ }^{35}$ Ekmeleddin Ihsanoglu, The Islamic World in New Century. p 133

${ }^{36}$ Edga Chavez et al, Mindanao: Understanding Conflict 2011, Conflict Management Program, Student Field Trip to Mindanao, John Hopkins University, School of Advanced International Studies, p 216-217. Accessed on May 2012. http://www.sais-jhu.edu/academics/functional-studies/conflict-management/pdf/MindanaoReport_Complete_Report\%20April\%205.pdf

${ }^{37}$ Resolution No. $10 / 4$ on the Situation of Muslims Throughout the World adapted at the Fourth Islamic Conference of Foreign Ministers Meeting in Benghazi, Libya, 24-26 March 1973. Official Website of the OIC, accessed on May 2012. http://www.oic-oci.org/english/conf/fm/All\%20Download/Frm.04.htm\#RESOLUTION No. 10/4

${ }^{38}$ Dr. Sarawut Aree, a researcher at Muslim Studies Centre, Chulalongkorn University, Bangkok. ñNayobai OIC Tor Panha Chon Klum Noi”: (OICôs Policy towards Minorities).
} 
relatively small compared to the number of population of the majorities, such as Muslims in Korea or in South American regions. The main problem of this group of Muslims is their religious culture is vulnerable to threats. Their urgent need therefore is to preserve their religious culture by getting support in establishing Islamic education or building Masjids (Mosques) for them to perform their religious rites. Muslim minorities therefore are different in terms of the atmosphere that they live and difficulties which they face.

One of the OICôs mandates as stated in its Charter is to safeguard the right of Muslim Minorities and Communities in non-OIC member states. The Charter says that the OIC mandates its General Secretariat to cooperate with other international and regional organizations to guarantee the rights of Muslim Minorities and Communities in non-OIC Member States, and promote close cooperation with the Governments of the States hosting Muslim communities. To this end, the OIC has to deal with non-member states with great respect to their sovereignty and integrity. Two prevailing reasons that could be seen as a pretext for the OIC in its mission toward safeguarding Muslim Minorities and communities in non-member states, the sense of Islamic Ummah which binds Muslims together by religious factors rather than territory and humanitarian intervention in the name of the protection of human rights with exceptional concentration on religion, as an element that binds Muslims together.

It is quite understandable that the OICôs mission relating to Muslim Minorities and Communities in non-member states is not as smooth compared to its dealings with member states. The OIC could not carry out its mission alone without coordinating with the states that host the Muslim minorities. The reality that should be noted is that even though the OIC, as a transnational organization, could influence the states in shaping its policies toward Muslim minorities but without close cooperation from the host state the OICôs effort might not gain any fruitful results as it should.

During the past times, the OIC attempted to intervene into non-member statesô affairs in order to address the issues of the Muslim minoritiesô rights. For instance, the issues of Muslim minorities in Southeast Asia, such as Myanmar, Thailand and the Philippines, have highly attracted the attention of the OIC. ${ }^{39}$ What could be evident from such attempts is that the degree of intervention varied depending on the influence of different states. Furthermore,

\footnotetext{
${ }^{39}$ Fred R. von der Mehden, Two Worlds of Islam: Interaction between Southeast Asia and the Middle East, The University Press of Florida, 1993. 54-55
} 
states that experienced intervention by the OIC responded in different ways in accordance with their position or power politics in the world community, or at least in the region. China for instance, has never showed any remorse when it was criticized by the OIC on how it handles the Muslim minority of Uyghurs in a remote region of China, Xinjiang. ${ }^{40}$ The Indian government always criticized the OIC for its stance on the issue of Kashmir and was dissatisfied with the press release issued by the OIC on that matter. The Indian government viewed the OICôs action as interference in its internal affairs ${ }^{41}$ and complained that it was done under pressure from its rival Pakistan, a very influential member of the OIC. ${ }^{42}$

When the issues of Muslim minorities are brought into the attention of the OIC a formal statement of the Secretary General of the OIC would be issued. The statement usually shows the OICôs concern for the violation of human rights suffered by Muslim minorities. The statement would then be followed by close monitoring by the Department of Muslim Minorities and Communities of the OIC which will prepare a report to the Secretary General. If the situation has not improved the reaction of the Member States of the OIC will be followed by a collective stance towards the issue or, at the very least, show their sympathy for the Muslim minority in the forum. If the situation is escalated a separate resolution may then be proposed. The separate resolution is seen as a means to put pressure on the country that host the Muslim minority urging it to respect their rights.

\section{The OIC and the conflict in the Philippines}

The most prevalent intervention of the OIC into the affairs of a Muslim minority was its role as mediator in the peace dialogue between the government of the Philippines and Moro Muslims in an attempt to end the long conflict between both parties. A peace agreement was seriously pursued after the massacre of Jabaria in $1968^{43}$. The Government of the Philippines responded to the Muslim rebellion by exercising heavy handed measures in the belief that the Muslim militant group could be finally pacified. The conflict rose to its peak and led to the attention of the OIC. In 1972, at the third Islamic Council of Foreign Ministers Conference (CFM) held in Jeddah, a resolution on the Situation of Muslims in The Philippines was

\footnotetext{
${ }^{40}$ Wilson John, Pakistan: the Struggle Within, India 2009. 162 see also Sandra Ruth Leavitt, ñPersuasion, Coercion, and Neglect: Understanding State Policy and the Mobilization of Muslim Minorities in Asiaò (PhD Diss., Georgetown University, 2007).

${ }^{41}$ Rajendra Madhukar Abhyankar, West India and The Region: Defining Indiaô Role, New Delhi, India, 2008. 247

${ }^{42}$ Mohan C. Bhandari, Solving Khasmir, India 2006. 225

${ }^{43}$ Ramses Amer and Keyuan Zou, Conflict Management and Dispute Settlement in East Asia, 2011. 66
} 
adopted $^{44}$. It expressed serious concern over the Muslims situation in the Philippines and sought the Government of the Philippinesôgood offices to guarantee their safety and property rights. The conflict has attracted the attention of many Arab countries especially Libya. It is taught that the Peace Agreement was a success due to Libyaôs involvement as a vital role player to bring the Peace Agreement into the sphere of the OIC. The then Libya leader, Col. Muammar Qaddafi signalled to the government of the Philippines in a very aggressive manner and warned the government of the Philippines that Libya ñwill be compelled to shoulder its responsibilities toward the four millions Muslims in the Philippinesò. ${ }^{45}$ Libya was known to provide financial support to Muslim militant groups. It its attempt to intervene in the conflict, Libya approached several countries in the OIC to take necessary measures to pressure the Government of the Philippines to comply with the demand of the Sothern Muslims. Libya suggested that the OIC members should impose sanctions against the Philippines but this was rejected by the majority of the OICôs members. It is because of the relatively heavy-handed diplomacy of Libya that other OIC member states decided that the OIC should intervene and handle the issue under the OICôs umbrella to avoid any negative impact that might be caused by Libya. ${ }^{46}$

Although the Peace Agreement was initiated in 1976, until recently the Agreement was not a success due to some limitations and obstacles that stood in the way of its implementation. Interestingly, the Moro National Liberation Front (MNLF) was granted status as an observer in the $\mathrm{OIC}^{47}$ (in Muslim communityôs category) which is, until recently, considered as a hindrance to the Government of the Philippines to obtain the same status in the organization despite long negotiations between the Philippines and the OIC. As a result, the Government of the Philippines perceive that the OIC attaches greater importance to the MNLF rather than to the Philippines as a sovereign state.

From the outset of the establishment of the OIC, its scope of functions was quite limited, but it then became wider to cover several aspects concerning the Islamic world. The work of the OIC relies on the concept of Ummah, as an international community bound by religious faith beyond conventional boundaries. To carry out its mission, the OIC therefore, must inevitably

\footnotetext{
${ }^{44}$ Max L. Gross, Islam Archipelago: Islam and Politics in Southeast Asia, Center for Strategic Intelligent Study (US), Government Printing Office, 2007. 187

${ }^{45}$ Ricardo A. David Jr., The Causes and Prospect of the Southern Philippines Secessionist Movement. Naval Post Graduate School, Monterey, California. December 2003. p. 76

${ }^{46}$ Ibid, p 77

${ }^{47}$ Ralph H. Salmi, Cisar Adib Majul and George K. Tanham, Islam and Conflict Resolution: Theories and Practice, University Press of America 1998. 164
} 
act beyond the boundaries of its member states since the Muslim population does not reside only within the Islamic statesôboundaries. The OIC has to be very conscious in exercising its mandates in non-Islamic states so as to maintain respect for the sovereignty of states, as a good institution, and to protect the rights of Muslim minorities for the betterment of the Islamic Ummah as it claims. 


\section{Chapter II: Southern Thailand Conflict:}

The last chapter reviewed how the OIC has developed, overtime, to cope with new challenges facing the Islamic world. At the outset of its establishment, the OICôs scope of mission seemed very limited and was very much related to the reasons that it was established. The scope of mission has grown to cover a wider area of concerns in accordance with the changes witnessed in the world. From a very narrow area, the OIC began to involve itself with nonmember states with the intention of protecting the rights of Muslim minorities in non-Islamic states. The OICôs mission was a combination of promoting universal rights and protecting Muslim minorities as a religious mandate constituted in the global concept of ñUmmahò

In this chapter, I will present an overview of the history of the Thai conflict. I will begin with a brief review of the historical background of the conflict as well as separatist movement in the region, throughout the time, and the nature of the conflict. It is also worth mentioning that up to date no specific causes for the conflict are identified due to the fact that various dimensions such as ethnicity, political grievances, social disparities and economic difficulties are all involved. Despite the mixed possibilities of root causes, the OIC involvement in the conflict began through what the OIC believes to be necessary. Through the OICôs perception the conflict in Thailand involving the Muslim minority is inevitably its gracious mandate to protect the Muslimôs rights.

\section{Southern Thailand Conflict: Historical Background, Separatist Movements and the Nature of Conflict}

As a starting point, it would be useful to trace back a brief history of the region. This is relatively important in order to understand the nature of the conflict that seems unlikely to end in the near future. The current wave of insurgency, which sparked in 2004 and shows no sign of ending, is considered as the longest that has ever occurred in the conflictô history.

The current wave of insurgency in the southernmost provinces of Thailand, namely Pattani, Yala and Narathiwat, which sparked up in 2004, is a security dilemma for the Thai government in recent days, the insurgency occurs on a daily basis and shows no sign of ending in the very near future. During the period, the insurgency has risen and fallen, appeared and faded away, but never totally disappeared from the region. Statistically, the current wave is considered to be the longest wave to have ever occurred in the history of the conflict between the ethnically Malay Muslims in the south of Thailand and the Thai 
authorities, with a variety of insurgent styles. Unlike other insurgencies elsewhere in the world, no particular insurgent groups, up to date, have ever claimed responsibility or publicly declared their objectives, since the current unrest began ${ }^{48}$. Although the nature of the conflict and its root causes are still debated among observers, many of them are more likely to stress the ethno-religious dimension fuelled by economic deprivation and historical grievances. The saliency of the conflict has always shifted. But the religious and ethnic factors are never far from the scene. The conflict is thus viewed as a rivalry between Islam or Muslims and Buddhists, or between Malay Muslims and Thais. However, the saliency of religious factor may be more prevalent rather than other factors.

\section{The Historical Background of Patani}

Thailand is considered to be a heterogeneous society, where there are a diversity of ethnic identities, in terms of races, cultures, religions and languages. One of the minority groups that exist within Thai society is Malay Muslim, residing in the southernmost provinces of the country, nemely Pattani, Yala, and Narathiwat. Unlike other ethnic groups in Thailand, the people in these three provinces formerly constituted an independent kingdom known as Patani. The majority of the people in these three provinces are Muslim with Malay ethnicity. Their characteristics are distinct from other ethnic groups within Thailand. Their religion is Islam; they speak "Jawi", which is a Malay language of their own local dialect. Their culture tends to have many connections with Malay culture rather than with Thai culture ${ }^{49}$. Obviously, because of the insurgencies that have occurred, throughout recent history, and the emergence of the current wave of insurgency, these provinces are considered to be a political problem to the Thai authorities and less likely to be totally integrated with their fellow nationals, Thais. The people in these three provinces seem reluctant to integrate themselves into the main society as is desired by the Thai authorities. ${ }^{50}$

\section{Patani Pre-annexation}

Historically, the provinces of Pattani, Yala and Narathiwat, were once an independent kingdom known as the Kingdom of Patani. The word ñPataniò indicates the former kingdom,

\footnotetext{
${ }^{48}$ Jayshree Bajoria and Carin Zissis, ñThe Muslim Insurgency in Southern Thailandò, Council on Foreign Relation, September 10, 2008. Accessed May 17, 2012. http://www.cfr.org/thailand/muslim-insurgencysouthern-thailand/p12531

${ }^{49}$ Patrick Jory, Thai South and Malay North: Ethnic Interactions on a Plural Peninsular, NUS Press: National University of Singapore, 2008. 157

${ }^{50}$ Ibid, 161
} 
before it was incorporated into the Kingdom of Siam ${ }^{51}$, while currently ñPattaniò is a province located in southern Thailand, along with another two provinces, Yala and Narathiwat, in the area included in the former Sultanate of Patani. ${ }^{52}$ Patani was believed to be founded in $1350 .^{53}$ The king of Patani declared his kingdom an Islamic state in 1475 after he embraced Islam as his religion. The kingdom of Patani was also known as ñPatani Raya" ${ }^{25}$ or the ñGreater Patani”. The kingdom was bordered to the north by the Kingdom of Siam and to the south by Malaca. The people in Patani are ethnically Malay, their everyday language is Jawi; a Malay language with their very own local dialect, nearly the same as that spoken by people in the northern region of Malaysia, Kelantan, Terengganu and Kedah. According to the history of the region, the kingdom of Patani was once a cradle of Islamic education in South East Asia, in the form of the traditional Islamic boarding schools called ñPondokò. The kingdom had a very significant role in producing many Islamic scholars, within the region. Furthermore, in terms of its status among the nation of South East Asia, the kingdom of Patani was one of the most prosperous states in the region ${ }^{55}$ and also a major trading centre with a strategically located seaport ${ }^{56}$ linking trades between Asia and Europe. Due to its strategic location and trade orientation in the region, Patani was a target of influence both from the north by the Kingdom of Siam, and from the south by the Kingdom of Malaca.

In terms of culture, the people of Patani were aligned with Malaca but politically, they were under Siamese suzerainty. When Malaca was defeated by the Portuguese in 1511, Malaca was unable to protect Patani from Siam. As a result, Patani had no other choice but to enter a tributary relationship with Siam to maintain the Kingdomôs stability and protect it from outside attacks. By entering into a tributary relationship with the Kingdom of Siam, Patani was inevitably obliged to pay an annual tribute amount of gold flowers called ñBunga Masò to the Kingdom of Siam. Interestingly, although Malay elites viewed this gift as a symbol of

\footnotetext{
${ }^{51}$ Siam is a former name of Thailand. According to the First State Convention on National Day 1939, the name of the country had been changed from Siam to Thailand. Source: Scot Barme, Luang Wichit Wathakan and the Creation of a Thai Identity, Institute of Southeast Asian Studies, Singapore, 1993. 147

52 The word ñPatani" refers to the former Sultanate of Patani before annexation to the Kingdom of Thailand, while ñPattaniò is a province of Thailand in the area included in the former Sultanate of Patani.

${ }^{53}$ Geoffrey C. Gunn, History Without Borders: the Making of an Asian World Region, 1000-1800, The Patani Sultanate: Facing down Siam, Hong Kong University Press, 2011. 95

${ }^{54}$ WK Che man, Muslim Separatism: The Moros of Southern Philippines and the Malays of Southern Thailandò. Oxford University Press 1990, Singapore, p. 32

${ }^{55}$ Bougas Wayne, Patani in the Beginning of XVII Century. In: Archipel, Volume 39, 1990. pp.113-138. Dol: 10.3406/arch.1990.2624 http://www.persee.fr/web/revues/home/parescript/article/arch_0044-8613_num_39_1_2624

${ }^{56}$ Edgardo Pedro Legaspi, Case Study of Ethnic Conflicts in Southern Philippines and Southern Thailandô $6^{\text {th }}$ Asia-Europe Round Table Minority Conflict-Toward an ASEM Framework for Conflict Management
} 
friendship with Siam; the latter considered it as a symbol of allegiance. ${ }^{57}$ Being a suffragan state, some commentators viewed Patani as a vassal of Siam with local autonomy while maintaining its relations with Siam $^{58}$. Throughout the Ayutthaya period in Siam and into the Bangkok period, Patani proved to be a troublesome vassal to Siam. Whenever Siam seemed weak, Patani would, at the very least, stop paying the tribute. In 1564 open revolt broke out when a Patani unit, called to assist Siam against the Burmese, instead seized the Kingô palace. Other uprisings occurred in 1630, 1633 and 1767 after the Burmese ransacked Ayuthya. Throughout this period the Siamese government took an indirect divide and rule approach to governing Patani, splitting the territory up and cultivating rival elites to administer the separate pieces under the observance of the administration of a southern Thai city. This approach succeeded in keeping Patani mostly divided and a vassal of Siam for five centuries.

In early 1785, under King Rama I of Siam, as a result of the southward expansion of Bangkok, Patani was incorporated as an integral part of the Kingdom of Siam. The incorporation caused some dissatisfaction among the Patani rajas and elites as they lost their power and autonomy and being marginalized, resulting in the occurrence of rebellions, from 1789 to 1791. The people of Patani regarded the incorporation as an occupation and conquering of its territory by Siam. Such sentiments continue to spread generation after generation, up till current days.

\section{The annexation of Patani into Thailand}

In 1785, after conquering Patani, as perceived by Malay Muslims, under the reign of King Rama I, the founder of the current Thai dynasty, Patani was officially incorporated into the Kingdom of Siam, together with the Malay sultanates of Kedah, Kelantan and Terengganu, (Malaysia) and became tributary states ${ }^{59}$. From 1791 up to 1808 , several rebellions, by Malay Muslims, occurred due to their dissatisfaction with being under the rule of Siam ${ }^{60}$. In an attempt to weaken the Malay Muslim backlash and power, the Siamese government abolished the Patani Sultanate and subdivided the area into seven smaller provinces: Saiburi, Pattani, Nongchik, Yala, Yaring, Ra-ngae and Raman. However, this divide and rule policy did not

\footnotetext{
${ }^{57}$ WK Che Man, Muslim Separatism, p.34

${ }^{58}$ Thanet Aphonsuvan, History and Politics of the Muslims in Thailand, Thamasat University, Bangkok, 2003, p 12

${ }^{59}$ Max L. Gross, A Muslim Archipelago: Islam and Politics in Southeast Asia, Government Printing Office, 2007. $59-60$

${ }^{60}$ Ibid. 60
} 
totally succeed in controlling the former kingdom of Patani; it did not stop the seven provinces from rebelling against Siamese rule, but the rebellions further resulted in Kedah being subdivided into two parts.

Throughout the history, the period of post-annexation of Patani is considered as a significant turning point in the relations between the Muslim people in southern Thailand and the Thai government, which will be discussed later. Several measures were taken in order to overcome the issue of identity gap. Some initiatives aimed directly at assimilating Malay Muslims into the main society of the nation, while others constituted initiatives which were intended to build the Thai nation, influenced by westernizing trends, to become a modern state ${ }^{61}$. All of these actions inevitably affected Thai Malay Muslims and thus are considered as crucial factors in the mobilization of the conflict between Muslim people in the south and the Thai authorities.

There are many crucial things that could be considered crucial factors in creating the conflict between Malay Muslims in the south with the Thai authorities. These factors could be summarized as historical grievances, constituted in the forms of ethno-religious dimensions, social and economic deprivations.

\section{Nationalism under Field Marshal Phibulsongkram}

Nationalism is an ideology that uses national identity as the basis for social and political action aiming to maintain state power in the form of a nation state. ${ }^{62}$ In order to motivate Siamố citizens and pursue a national goal to gain a collective identity as aimed by the authority, the ñRathaniyomò, or Thai Cultural Mandates, was promulgated beginning, precisely, in 1939, under the administration of Marshall Phibulsongkramôs ultra-nationalist pan Thai government. The decree of 12 conventions, issued from 1939 to 1942, consisted of nationalistic policies that affected Thais and Muslims as well as other minorities, throughout the country ${ }^{63}$. Progress and civilization was brought forward in an attempt to modernize (Westernise) Thailand at the same time as ñThainessò was encouraged. Everything considered to be Thai was promoted and many minority groups, as well as Siamese, found it difficult to adapt to the new ideas. The idea was to make the Siamese people truly Thai.

\footnotetext{
${ }^{61}$ Patrick Jory, Thai South and Malay North: Ethnic Interaction on a Plural Peninsula, National University of Singapore 2008. 106

${ }^{62}$ Robert Anderson, National Identity and Independence Attitudes: Minority Nationalism in Scotland and Wales. Centre for Research into Elections and Social Trends, working paper No. 86, September 2001.

${ }^{63}$ Nicholas Tarling, The Cambridge History of Southeast Asia: The Nineteenth and Twentieth Centuries, Cambridge University Press, 1992. 299
} 
Many of the policies were seen by the Malay Muslims and other ethnic identities in the country as offensive. ${ }^{64}$ In this attempt to westernize the Thai nation, the requirement to take a Thai surname (which Thais, at the time, did not traditionally use) was introduced ${ }^{65}$. Field Marshall Phibulsongkram encouraged the adaption of Western culture such as, men kissing their wives in public and required western dress, including westernized womenôs hats, in public. These regulations forced the Malay Muslim population to forego their unique traditional Muslim dress and deportment. They overturned the special status of Islamic law over inheritance and family matters. They even required the use of forks and spoons, instead of using hands, as the ñational cutlery.ò The imposition of western culture was seen by many Buddhist Thais as an affront to their traditions, but to Malay Muslims in Patani it was an affront not only on their cultural traditions but also to their religion.

Under the new order central governance and secular law replaced local customs and religious laws. The Masjid (Mosque) was no longer the centre of the village. To further exacerbate the changes, family and inheritance laws, widely practiced among Muslims in the southernmost provinces, were administered in accordance with Sharia law, but these decisions could now be overturned by a secular Thai judge on appeal ${ }^{66}$. In the southern areas there was little formal education amongst the Malay children. In most of the country, government education officials and Buddhist monks implemented the reforms. In the southernmost provinces where, if there was any opportunity for education, it was limited to memorization of the Quran. The reforms were implemented by the government without local or religious assistance ${ }^{67}$. The state-building nationalist plan attributes the efforts of state to incorporate culturally distinctive regions while peripheral nationalism occurs when a culturally distinctive territory resists incorporation into an expanding state, or attempts to secede and set up its own government.

In general, the process of Thai nation-building generally isolated Malay Muslims, as they are ethnically Malay and culturally Muslim, in contrast to the Thai Buddhist majority. Malay Muslims, whose allegiance had been to the sultans, throughout the history, found that the relationship, between Thai Buddhists and Malay Muslims was now superseded by the Thai ñationalò interest.

\footnotetext{
${ }^{64}$ Judith A. Stowe, Siam Becomes Thailand: A Story of Intrigue, London, 2008. 200

${ }^{65}$ Nicholas Tarling, The Cambridge History of Southeast Asia. 300

${ }^{66}$ Aphornsuvan, "History and Politics of the Muslims in Thailand, p. 15.

${ }^{67}$ Ibid 17.
} 
In his book ñThailand: A Short Historyò, David Wyatt suggests that the reign of King RamaV (King Chulalongkorn) witnessed the beginning of official Thai nationalism with its primary targets on religion and education. As a result, the process succeeded in unifying the Thai nation both politically and in terms of language and culture. On the other hand, it excluded the non-Buddhist and non-Thai speaker. Wyatt writes:

With these religious and educational changes came the development of a new civic sense. To a certain extent it sprang naturally from the changes, from sharing in a common religious tradition and educational experience. Both constituted new modes of social communication, those means by which a society becomes conscious of its own identity. The schools, the temples, and the contacts with government officials $ठ$ all reinforced the idea that all inhabitants of Siam were subjects of a single king, members of a single body politic. For the time being, these ideas were expressed primarily in hierarchical terms analogous to the old patron-client relationship that pervaded the traditional society. All the inhabitants of Siam $\ddot{i}$ including countless non- Siamese, as we shall see were now clients of the same patron, the king. Obligations once owed a patron were now owed the king: loyalty, obedience, taxes, military service, education, proper behavior. In return, the king owed them security, protection, justice, compassion, help in time of need, moral example, and so on. This basic idea was, in a sense, a compromise between the old concept of the óubject,ôstripped of the intermediaries that stood between the king and the peasant, and the modern concept of the áitizen.ô It combined elements of both, and the contradictions inherent in the combination remained to worry history subsequently. ${ }^{68}$

\section{Divide and Rule}

After the annexation of Patani by Siam (later Thailand) the Thai authorities under the reign of King Chulalongkorn decided to divide Patani into seven smaller provinces. The aims of the divide and rule policy was to accelerate the process of assimilation and centralize the administration. The aim also was to weaken Malay Muslim identity and the fear of increasing threat from the British in Malaya. ${ }^{69}$ This policy, of course, created anxiety amongst Patani

\footnotetext{
${ }^{68}$ David Wyatt, ñThailand: A short History. New Heaven: Yale University Press, 2003, p. 202-203

${ }^{69}$ SP Harish, Ethnic or Religious Cleavage? Investigating the Nature of the Conflict in Southern Thailand. Contemporary Southeast Asia Vol. 28 No. 1(2006) pp. 48-69. P. 51
} 
rajas and elites as it marginalized their roles and threatened the identity of Malay Muslims as a whole.

\section{Historical Grievances:}

\section{Anglo-Siamese Treaty $^{70}$}

In 1909, the Anglo-Siamese Treaty was signed by the British government and the Kingdom of Siam. As a result, a border was agreed between Patani and the Malay states of Kelantan, Perak, Kedah and Perlis, in British Malaya. Patani was divided into three provinces, Pattani, Yala and Narathiwat and Thai officials with no background knowledge of the local culture and language were appointed and were under the direct supervision of the central government in Bangkok.

\section{Thai Nation Building}

During the late 1930s, under the administration of Field Marshall Phibunsongkram and his ultra-nationalist Pan-Thai policy the confrontation between Malay Muslims and the Thai authorities again escalated. The policy aimed at imposing central cultural mandates, known in Thai as Rattaniyom, to assimilate ethnic minorities. The policy was viewed by Malay Muslims in the south as an attack on their cultural and religious identities. Government primary schools in the south were obliged to set up Buddha statues and Malay Muslim children were forced to bow before them..$^{71}$ The policy also aimed at changing the identity of Malay Muslims to be ñThai Muslimò.

Being under threat, Malay Muslims had to make a decision whether to be with the Thai authorities in all aspects of their life or to secede from the Thai state and seek to govern themselves.

\section{Malay Muslim Separatist Movements}

To begin the history of the conflict between Malay Muslims and the Thai authorities in the southernmost provinces it would be useful to shed light on separatist movements in the region. By understanding the separatistsô movements and their objectives in the struggle

\footnotetext{
${ }^{70}$ Michael J. Montesano and Patrick Jory, editors., Thai South and Malay North: Ethnic Interaction on a Plural Peninsular, National University of Singapore, 2008, p 91

${ }^{71}$ Southern Thailand Insurgency not Jihad, Asia Report No 98 ï 18 May 2005., International Crisis Group, p 3
} 
against the Thai authorities we might gain a clear picture of the nature of the conflict that has arisen and fallen, throughout the times.

Historically, although there has been several times of rebellions against the Thai authorities since the Patani kingdom was officially annexed into Thailand, most of the activities, at the outset, were carried out by individuals and various uncoordinated groups. Along the history of Malay Muslimôs separatist movements three major groups could be considered as organized groups appeared on the scene. The Pattani United Liberation Organization (PULO), the Barisan Rivolusi Nasional (BRN) and its affiliates the BRN-Coordinate and Barisan Islam Pembibasan Patani (BIPP), formerly known as Barisan Nasional Pembibasan Patani (BNPP). The following passages would be about those separatist groups and their motivations in struggling to gain their specific political goals.

\section{GAMPAR: The first movement post-annexation era}

Gabongan Melayu Patani Raya (GAMPAR) or United Malays of Greater Patani was the first structured movement to be involved in campaigning for the unity of Malay Muslims in the southernmost provinces of Thailand. The organization was formed on 3 March 1948 with one of the Patani rajas as its first leader, Tengku Ismail bin Tengku $\mathrm{Nik}^{72}$, along with other Malay elites who suffered being marginalized during the centralization process and the divide and rule policy carried out by the Thai authorities. ${ }^{73}$ It is because of the Malay Muslimsô dissatisfaction that GAMPAR emerged, especially the reactions from Malay elites which was carried out by the Thai authority.

One of the significant aims of GAMPAR was to unite all south Thailand Muslims and their descendants who resided in Malaysia and to promote Education and revive Malay culture in Thailand.

As stated in its manifesto, the three main objectives of the GAMPAR were:

1. To unite the four provinces of Pattani, Yala, Narathiwat and Satun as a Malay Islamic state and liberate residents from oppression and exploitation;

2. To establish a state appropriate to Islamic tradition and practices to meet the demands of the Malay Muslims and;

\footnotetext{
${ }^{72}$ The title ñTengkuòin Malay Language is acronym to ñPrinceò in English

${ }^{73}$ Omar Farouk, ñThe Historical and Transnational Dimensions of Malay-Muslim Separatism in Southern Thailandò. Armed Separatism in Southeast Asia, edited by Lim Joo-Jock and Vani S. pp. 234-57. p. 53. Institute of Southeast Asian Studies.
} 
3. To improve the status and quality of life of the Malay Muslims in the areas of humanity, justice, freedom and education without delay

Even though GAMPAR clearly advocated creating a separated state and incorporating it with the Federation of Malaya, according to Haris this did not mean that GAMPAR emphasized only nationalist dimensions without any role of religion in its struggles against the Thai authorities. The main issue was that the religious rhetoric was well used and mobilized to gain support from neighbouring Islamic states like Malaysia, Indonesia and Pakistan. In the meantime, GAMPAR also aimed at gaining all possible support from international Islamic organizations such as the Arab League, as well as wider international organizations like the United Nations or transnational Islamic organizations like the organization of the Islamic Cooperation. At the time, GAMPARôs struggle against the Thai authorities attracted little attention among Islamic states and organizations since the discrimination claimed by GAMPAR were viewed by the outside world as having no relation to religion, but rather with ethnicity.

In sum, the overall picture of GAMPAR was seen as a political organization aimed to liberate the four provinces of southern Thailand and to merge those provinces with the Federation of Malaya. During the period, the religious factor was less salient in the struggle against the Thai authorities. Fighting for the cause of the Malay ethnicity in the southernmost provinces of Thailand was more emphasized.

\section{Haji Sulong and the struggle against the Thai authorities}

It is worth to mention that during the same period of time, in the late 1940s, a chairman of Pattani Provincial Islamic Council, Haji Sulong (Sulong bin Abdulkadir bin Muhammad el Patani), a prominent Muslim scholar and one of the most influential religious figures in southern Thailand also played a significant role in struggling against the Thai authorities. The most historical struggle that drew very much attention in the Islamic world and emphasized heavily on Islamic elements was Haji Sulongôs presentation of seven demands to the Thai authorities for the improvement of the lives of Malay Muslims in four provinces of southern Thailand.

The emergence of Haji Sulong added another important turning point to the history of conflict between Malay Muslims in southern Thailand and the Thai authorities. Prior to his emergence, the conflicts and struggle of the Malay Muslims was concentrated on the 
leadership and power of the Patani rajas and their elite personalities. In a sense, the previous struggle was very much structured within the hierarchical social relations between the Siamese kings and the Malay rajas of Patani. As a result, the historical narrative of the conflicts filled with struggle to compete for interest and powers of the rajas and elites, instead of fighting for the peopleâs dignities. On top of that, the narrowness of the political ideologies of the Malay power elites. During the period, Islam as a driving ideological and political force was less likely to be prevalent, or even, to some extent was absent from the scene.

\section{Haji Sulong's Seven Demands:}

Educated in Mecca, Saudi Arabia, Haji Sulong was heavily influenced by the reformist idea of Jamal al-Din al-Afghani and Muhammah Abduh $^{74}$. After the establishment of Patani Peopleôs Movement (PPM) in early 1947, Haji Sulong, the founder of the movement submitted his petition demanding from the Thai authorities self-rule, language and cultural rights and implementation of Islamic Law. Haji Sulongôs seven demands were ${ }^{75}$ :

1. The appointment of a single individual with full powers to govern the four provinces of Pattani, Yala, Narathiwat and Satun, and in particular having authority to dismiss, suspend or replace all government servants. This official to have been born in one of the four provinces and elected by the people;

2. 80 per cent of government servants in the four provinces to be Muslims;

3. Both Malay and Thai to be official languages;

4. Malay language to be the medium of instruction in primary schools;

5. Islamic law to be recognized and enforced in a separate court other than a civil court where non-Muslims sat as assessors;

6. All revenue and income derived from the four provinces to be utilized within them; and;

7. The formation of a Muslim Board having full powers to direct all Muslim officers under the supreme head of state mentioned in (1).

Although the seven demands of Haji Sulong did not clearly indicate the intention to secede the southernmost provinces from the central government of Thailand, the demand did imply that the conflict between Malay Muslims in the four provinces of Thailand with the Thai authorities related to both religious and ethnic dimensions. The seven demands could be

\footnotetext{
${ }_{75}^{74}$ Southern Thailand Insurgency not Jihad, Asia Report No 98 ï 18 May 2005., International Crisis Group, p 5

${ }^{75}$ Ibid, p 5
} 
considered as a significant turning point in the history of the conflict in the region, if it was taken into consideration seriously by the Thai authorities. Undoubtedly, Haji Sulong and other Malay Muslim prominent figures viewed the demands as a crucial key to sustaining peace in the southmost provinces of Thailand. Instead, the Thai authorities responded by arresting Haji Sulong, together with several other religious leaders and parliamentarians on treason charges in January 1948. As consequence, many others escaped and carried on the struggle from Malaya.

The imprisonment of Haji Sulong led, inevitably, to the escalation of the conflict in the region. Malay officials in Pattani, Yala and Narathiwat boycotted meetings with administrators and showed their subordinate responses against the central government. The non-cooperation strategy soon turned into open confrontation with the authorities. Furthermore, the arrest of Haji Sulong was one of the factors behind the severe unrest that broke out in 1948. Protests and riots against the governmentôs action erupted all over Pattani, Yala and Narathiwat. The most serious incident occurred in Duson Nyor district, Narathiwat province. The incident was later known as ñDuson Nyor Rebellionò. A religious leader, Haji Abdulrahman led hundreds of protesters against the police, resulting in the death of some 400 Malay Muslims. Several thousand escaped to Malaysia. The Duson Nyor incident was held up as the onset of the modern violent struggle in the south. The current wave of insurgency could be considered as a historical repetition of Duson Nyorôs rebellion.

Interestingly, the historical narrative of the Duson Nyor incident, as represented by the Thai authorities, often uses the word ñrebellionò. ${ }^{76}$ The implication of this usage was to indicate the brutality of the riots carried out by Malay Muslims. In the local narrative the word ñWarò was preferred. ${ }^{77}$

\section{The emergence of armed movements}

Since the collapse of the GAMPAR the struggles in the region that followed were mostly carried out by individuals rather than organized groups. Some prominent leaders during the time of GAMPAR learnt their lessons from the mistakes of GAMPAR and the desperateness of the individual and unconstructed struggles. As a result, more constructed and more progressive movements were formed.

\footnotetext{
${ }^{76}$ Patrick Jory, Thai South and Malay North: Ethnic Interaction on a Plural Peninsular, National University of Singapore, 2008. 122

${ }^{77}$ Ibid. 122
} 


\section{Barisan Nasional Pembebasan Patani (BNPP)}

During the 1950s several attempts to establish a political organization supporting the cause of Malay Muslims in the Deep South through such groups as the United Greater Patani Malay Movement or Gabongan Melayu Patani Raya (GAMPAR) were witnessed. Later on, in the year 1959 Barisan Nasional Pembebassan Patani (BNPP) or Patani National Liberation Front was the first group to organize an armed struggle against the Thai authorities. The group was founded by a former member of GAMPAR and a Patani prince, Tengku Abdul Jalal. BNPP was the first organization that clearly called for an independent Patani with emphasis on the establishment of a state under the previous sultanate, unlike any other groups, which I will be discussing later. The majority of BNPP members were Malay Muslim elites and religious figures. ${ }^{78}$ Facing difficulties and limitations in receiving support from Islamic countries, as well as the call from within the organization to emphasize more on religious causes, rather than ethnicity, in 1986 the BNPP changed its name to the Islamic Liberation Front of Patani (Barisan Islam Pembibasan Patani, BIPP). The change of the name also led to reforming the groupôs manifesto to be more salient on the religious dimension. In recent days, it is thought that the BIPP is inactive in terms of armed struggle.

\section{The Pattani United Liberation Organization (PULO)}

The PULO or known in Malay language as ñPertubohan Persatuan Pembibasan Pattaniò. The group formally emerged in the late 1960s, led by Tengku Bira Kotanila. After the emergence of PULO it was the most influential separatist group in southern Thailand and became the most troublesome group to the authorities. The groupôs official ideology is ñReligion, Race, Homeland and Humanitarianò. ${ }^{79}$ Although it stated clearly that the goal of the group is to fight for an independent Patani, free from Thai occupation, and established as an Islamic state, some commentators viewed the group as more likely to emphasize ethno-nationalist dimensions rather than religious-centric.

The aims of PULO are as follows: ${ }^{80}$

- PULO is a political organization for the people of Patani. PULO aims to:

\footnotetext{
${ }^{78}$ Neil J. Melvin, Conflict in the Southern Thailand: Islamism, Violence and the State in the Patani Insurgency. SIPRI Policy Paper No. 20, p. 15

${ }^{79}$ In Malay language ñUgama, Bangsa, Tanah Air, Peri Kemaônusiaanò or in acronym ñUBANGTAPEKEMAò

${ }^{80}$ Satha-Anand, Islam and Violence: A case study of Violent Events in the Four Southern Provinces, Thailand p 15
} 
a. Unite all active political parties among the people of Patani against the Thai imperialist;

b. Unite and actively fight for freedom, world liberty against prevalent colonialists, both old and new. (We) will fight the imperialists in every way with strength and the force of weapons. (We) will especially fight the Israelis who occupy the Arabsôland;

- PULO has its own history and ideology which constitute a particular political military, economic order which is most conducive to the hopes, customs, and wishes of the people of Patani.

- The doctrine of the federation (sic) adheres to the concept of nation-state which is, in turn, defined by Islam, nationality and humanitarianism.

- Liberation of the Patani people in every level at all times. With all our might, the people of Patani will try and continue to fight for the freedom of Patani and the emergence of an Islamic Republic.

\section{Barisan Revolusi Nasional (BRN)}

The National Revolutionary Front or known in Malay language as Barisan Rivolusi Nasional, (BRN) emerged in the early 1960s. The group was founded by Ustaz Haji Abdul Karim Hassan, a religious teacher or ñTok Guruò in local terms. The reason for the formation of the group was thought to be resistance to the governmentôs educational policies which were seen by local Muslim people, especially religious figures, as an attack on their religious identity. ${ }^{81}$

Earlier, I mentioned the educational reformation policy in 1961 under the administration of Field Marshall Phibul Songkram. Under this reform policy the local Islamic institutions, Pondok, were obligated to include the official Thai curriculum into their system of education. Schools and institutions that refused to do so were simply ordered to close. The policy was seen by religious figures in the Deep South as an attempt from the authority to assimilate Muslims as well as to weaken the Malay identity and to take away any separatist sentiments created by Muslim Malay schools. As a result the BRN was formed with the aim of creating an independent Republic of Patani out of the four majority Muslim provinces, Pattani, Yala, Narathiwat, Satun and some parts of Songkhla.

\footnotetext{
${ }^{81}$ ñNo one is selfò, Human Rights Watch, Volume 19, No. 13(C), August 2007, Accessed May 2012. http://www.hrw.org/sites/default/files/reports/thailand0807.pdf
} 
At the outset of its emergence, BRN was much more focused on political organisation, particularly in religious schools, rather than guerrilla activities. It did not shy away from violence, however, and had a military wing led by Jehku Baku (alias Mapiyoh Sadalah), who commanded 150 to 300 men, mainly in Yala and some western districts of Songhkla province $^{82}$. In the 1960 s and $1970 \mathrm{~s}$, BRN maintained close relationships with the communist parties of Malaysia and Thailand, who shared the goal of destabilising the border areas. This cooperation alienated some of its more conservative supporters in Malaysia and the Middle East. BRN's efforts to span socialism, Islamism and nationalism made it particularly vulnerable to factional splits.

\section{Current Wave and trend of the conflict}

Even though the conflict in the deep south of Thailand between Malay Muslims and the Thai authorities has emerged since the 1940s, the scope of insurgency, in terms of the scale of casualties and the type of insurgency, has differed from time to time. The conflict has fluctuated in intensity but still shows no sign of ending. During the 1990s the insurgency, as caused by the conflict, was thought to be fading away, or at least weakening, due to several constructive measures taken by the Thai authorities in an attempt to overcome the problem. Furthermore, the governmentô endeavours in creating sustainable economic prosperities and lifting the living standards as well as promoting awareness of local cultures amongst officials were believed to be instrumental in calming down the unrest in the region. All of these measures were under the responsibility of the Southern Borders Provinces Administrative Centre (SBPAC) ${ }^{83}$ However, it was unfortunate that the Thai authorities, at the time, failed to take advantage of such good circumstances and a favourable atmosphere to deal with the problem in order to achieve a sustainable peace in the region. This was because the authorities underestimated the overall scale of the insurgency groups, believing that the old separatists groups had demised or at least did not have sufficient power to cause any trouble to the stability of the southern provinces. Without the awareness of the authorities during the relative calm period, a small military group under the wing of BRN-Coordinate (BRN-C) called Runda Kumpulan Kecil (RKK) or ómall patrol groupô The authorities believe that the

\footnotetext{
${ }^{82}$ Wan Kadir Che Man, Muslim Separatism: The Moros of the Southern Philippines and the Malays of Southern Thailand (OUP, 1990), p 99

${ }^{83}$ Peter Chalk, the Malay-Muslims Insurgency in Southern Thailand: Understanding the Conflictô Evolving Dynamic. National Defense Research Institute. p 9
} 
RKK is the group behind the current wave of violence in the region ${ }^{84}$. Unlike any other armed groups, the RKK does not publicly announce the identities of its leaders. As a result, it makes the problem in the south more complicated for the authorities to solve to the extent that some observers depict the conflict in the south as ớighting with a ghostô ${ }^{85}$

The current wave of insurgency is yet another reflection of the previous waves of conflict and unrests. Along the history of conflict, the insurgency rises and falls but has never abated. After a very long decade of relative calm in the deep south of Thailand, the unrest sparked its flame again in 2004. The recent upsurge of insurgency began with a pre-dawn raid on the $4^{\text {th }}$ Royal Army Engineering Battalion in Cho Airong District, Narathiwat province, by an estimated number of 50-100 armed men. ${ }^{86}$ The armed men were equipped with oxyacetylene cutting torches and bolt cutters to break into the battalionôs weapons stores.

\section{The shifting nature of the conflict}

From the beginning of the conflict up to today, the nature of the conflict seems to have shifted. At the outset of the struggle, the ethnic discord seemed to be the primary factor in the conflict. The group and individuals, at the time, clearly fought for the cause of Malay ethnicity, as a primary factor, with religious rhetoric as secondary. The conflict, at the outset, was seen as a conflict between Malay ethnics in the southernmost provinces and the Thai Buddhist authorities. The nature of the conflict, later on, changed from an ethnic emphasis to that of Islamic identity.

According to some observers, the Thai authorities have created an identity known as ñThai Muslimò in order to cultivate a sense of allegiance to the Thai nation. This is quite understandable. The Muslim population in Thailand can be categorized into 2 groups. First, Malay Muslims in the southernmost provinces of Thailand with Malay ethnicity, are a native minority in the country. This group is less likely to be integrated with core society in country. Second, Thai Muslims elsewhere in the country. This group is integrated. In order to cultivate the sense of allegiance to the Thai nation and to eradicate, or at least weaken, the sense of Malay Muslim sentiments the Thai authority created the term ñThai Muslimò. The reason

\footnotetext{
${ }^{84}$ Zachary Abuza, Conspiracy of Silence, The insurgency in Southern Thailand. United State Institute of Peace p 117

${ }^{85}$ Joseph Chinyong Liow and Don Pathan, Confronting Ghosts: Thailand Shapeless Southern Insurgency, The New Insurgency, Lowy Institute for International Policy, 2010, Paper No.30, 7-11

${ }^{86}$ Southern Thailand: Insurgency, not Jihad. Crisis Group Asia Report No. 98, 18 May 2005. P. 17
} 
behind the creation of a ñThai Muslimò identically was to weaken the attachment to ethnicity amongst Malay Muslims in the south.

Harish argued that, the shift in the nature of secessionist groups in the southernmost provinces of Thailand could be possibly caused by four reasons. First, the Thai authorityô continuous attempts, especially at the outset of Pataniôs annexation, to eradicate Malay identity from Malay Muslims in the south by imposing several assimilation measures causing dissatisfaction amongst Malay Muslims in the south. Second, the lack of support from Malaysia for the causes of Malay ethnicity caused the ethnic dimension of the conflict to be minimized. Third, the increasing trend amongst Malay Muslim youths to pursue their religious studies in the Islamic world, especially in the Middle East, where they were influenced by current thought across the region. Fourth, the post 9/11 environment caused changes in the young generationô perspectives. ${ }^{87}$

What could be evident from Harishôs argument is that at the outset of the conflict the struggle was very much for the cause of Malay ethnicity with religion as a secondary factor. When the struggle, at the time, did not attract much support from neighbouring and Islamic counties the conflict changed its saliency from ethnic emphasis to the religious cause. Some observers emphasize that the conflict is very much related to ethno-nationalism as the primary driver with religion as a secondary factor that led to the conflict, over the times. This dichotomy, according to Ian Storey is unsustainable ${ }^{88}$. Storey argued that Islam cannot be separated from Malay identity. Other observers see that Islam is becoming more salient in the conflict.

Currently, the insurgent group is targeting Thai Buddhist teachers in government primary schools. According to Dr. Srisompob Jitpiromsri, a lecturer of Political Science at the Prince of Songkhla University in Pattani, there are several reasons behind targeting teachers. Perhaps the most prevailing reason for the attacks is that teachers are considered as the authoritiesô symbol who carry out the authoritiesô program to eliminate Malay Muslimsô identity. Furthermore, by targeting teachers the insurgency groups can escalate the situation and indirectly put pressure on the authorities to sit at a negotiating table with the group. ${ }^{89}$

\footnotetext{
${ }^{87}$ S. P. Harish, Changing Conflict Identities: The Case of the Southern Thailand Discord, Institute of Defense and Strategic Studies, Singapore, February 2006. No 107, p 15-17

${ }^{88}$ Ian Storey, Ethnic Separatism in Southern Thailand: Kingdom Fraying at the Edge? Asia-Pacific Center for Security Studies 2007, p 3

${ }^{89}$ Cited in www.deepsouthwatch.org 23/11/2011 ñTam mai tong kha khru chaidaenò (Why killing Southern Border Teacher?)
} 
However, McCargo argued that the current wave of insurgency is not related to Islam. He emphasized that the causes of the conflict have something to do with historical and political grievances. Islam, however, is motivated as instrument and rhetoric for the militants to gain their goals. Furthermore, the conflict in the south of Thailand is not considered as a global jihad. It is a local ñtraditionalistò Islam. ${ }^{90}$

To sum up, the conflict in the southern provinces in Thailand has occurred since the annexation of Patani by Thailand. Along the time, the conflict has risen and fallen but never completely faded away from the region. Many possible factors may be considered as root causes of the conflict but the most salient cause seems to be the conflict of ethnicity exacerbated by religious dimension. The nature of the conflict has always shifted to meet the purpose that the various insurgent groups struggled for. It is of benefit to the separatist groups to gain support from the Islamic world or from any Islamic organization if the conflict is depicted as a religious rivalry caused by discrimination and abuse of civil or human rights. The Thai authorities must be very conscious in addressing the issue due to the sensitivity of the religious aspects of conflict that may be escalated. Although the root causes are complex and diverse in nature, the religious dimension would always be salient to attract the attention of the Islamic world.

\footnotetext{
${ }^{90}$ Duncan McCargo, Tearing Apart the Land: Islam and legitimacy in Southern Thailand, Cornell University, 2008. 187-188
} 


\section{Chapter III: Thailand and the OIC}

To shed light on the current situation in the southern provinces of Thailand and the role of the OIC I will discuss the beginning of relations between Thailand and the OIC. I will then trace the role of the OIC through the years. This part will investigate how the cooperation between both entities has developed and the sorts of difficulties that might have prevented achieving the goal of a sustainable peace. Given the differences between the natures of both sides, state versus non-state actor, the perceptions as viewed by either side are inevitably varied. This essay will look at the relations between Thailand and the OIC prior to the accession of Thailand to the OIC as an observer state. This chapter also will include what the OIC does in terms of the conflict in the south of Thailand and what are the consequences of its intervention into the internal affairs of Thailand. As the essay approaches to the details of the matter, we might get a clear picture of the overall circumstances surrounding the tension between an inter-governmental entity, in its attempts to preserve and uphold the universal rights of a Muslim minority, in the name of the global Ummah and a sovereign state which possess its own particular interests.

This chapter will begin by surveying the historical background of the OICôs involvement in the southern Thai conflict. By this, the essay will shed light on what the OIC has done, over the period. As a representative of its member states the OICôs actions will definitely be involved with its member states. In terms of the relationship between Thailand and most of the OIC member states, it could be said that it is relatively smooth, while the relationship with the OICôs General Secretariat seems to be quite different. As a result, this essay will consider the involvements of all actors in the scenario, so as to gain a clear picture of the main message of the essay which is related to the contention between the classical notion of state sovereignty and the role of non-state actors in enforcing the observance of universal rights. This chapter will then conclude with a summarization.

\section{The relationship between Thailand and the OIC}

To shed light on this topic it is worth mentioning that the relationship between Thailand and the OIC existed long before the OIC accepted Thailand as an observer state in $1998^{91}$. Thailand is amongst four countries enjoying observer status in the OIC today. The

\footnotetext{
${ }^{91}$ Observer states in the OIC are: Bosnia and Herzegovina (1994), Central African Republic (1996), Thailand (1998), and the Russian Federation (2005). See the official website of the OIC http://www.oic-oci.org/page_detail.asp?p_id=179
} 
engagement of Thailand with the OIC was understandable due to the fact that Thailand was known to have policy of engagement with the Islamic world in as many different fora as it deemed possible. To engage itself with the OIC framework, Thailand automatically created a gateway to the Islamic World in various fields of interest. In addition, the engagement of Thailand in the OIC fora would create a positive channel for Thailand in providing accurate and reliable information about Muslim minorities and communities in Thailand to the Islamic world, in general and to the OIC, in particular. This channel of information will be the most suitable instrument in order to avoid any misunderstanding which may occur to the OIC and the Islamic world. This is to confirm that Thailand would gain no benefit if it isolated itself from the Islamic world, whatever the circumstances in the country. The cooperation, of course, was aimed at government-to-government contacts within the OIC framework in all possible areas. In parallel, the Thai authorities aimed at preventing separatist groups from manipulating the OIC as a forum to internationalise the conflict and to use this as an instrument to gain their political goals in secession from Thailand. It is worth to mention that before the accession of Thailand into observer status within the OIC many attempts were carried out by Muslim separatist movements to gain observer status in the OIC. To the Thai authorities, the OIC could be manipulated by the separatist groups in struggling for their cause. The Thai authorities therefore needed to monitor the OICôs movement in a very careful manner. To this end, the good existing bilateral relationships with the OICôs member states would definitely help Thailand in preserving its interests.

To sum up, the possible reasons that made Thailand decide to engage itself directly with the OIC were to gain access to greater cooperation with the OIC in particular, and with the Islamic world in general, in parallel with other existing frameworks throughout various regional and international organizations. Through the OIC Thailand would gain not only good relationships with the Islamic world but would create a platform for the Thai authorities to present a clearer picture of how the Muslim minority in the country is being well treated. To gain direct access to the OIC meant that Thailand had another forum that could build a political bloc to create greater chances for mutual interests in all possible aspects. On the other hand, by gaining observer status in the OIC, Thailand can rest assured that no separatist groups from southern Thailand will be allowed to gain the same status in the OIC and hence give them opportunities to put pressure on the OIC, or on its member states.

In short, it could be said that the accession of Thailand to observer status in the OIC created positive chances for Thailand rather than any negative outcomes. 
The Thai authorityôs decision was remarkably valuable as it gained a two-pronged objective at the same time. The first reason was a highly passive one. It tends to be a value added benefit to Thai foreign policy which was seen as friendly in the region. Thailand enjoys very strong and good relations with almost all of the Islamic states both within the ASEAN region, with Malaysia, Indonesia and Brunei Darussalam, and outside the region with such countries as, including but not limited to, Pakistan, Iran, Egypt, Morocco, UAE, Bahrain and Qatar. The second prong was that by gaining observer status Thailand strongly possessed all political means to prevent separatist movements from gaining the same status, since the groups were in dire need of getting such status to pursue their goals.

\section{The relationship between the $\mathrm{OIC}$ and separatist groups}

As mentioned earlier, before Thailand became an observer state in the OIC, the relationship between the OIC and some separatist groups was relatively robust, especially during the rise of Pan-Arabism in the Middle East. The Arab struggles against colonialism, at the time, very much attracted the attention of Muslim separatists. The following passage gives a brief historical background of the relationship between the OIC and some separatist groups ${ }^{92}$.

Since 1974, the separatist movement, Patani United Liberation Organization (PULO), was very active in attempts to gain observer status in the OIC due to the fact that PULO had its own international bureau located outside Thailand, in Europe. On the other hand, PULO had unofficial relations with the OIC Secretariat in a very discreet way. In short, the battle between the Thai authorities and PULO within the OIC represent the picture of some Islamic states in the OIC who are allied with the Thai government, and the Secretariat who mostly spoke in favour of the separatist group. Since 1974, PULOôs attempts were sacked by some OIC members namely, Indonesia, Malaysia and Pakistan. In 1974, PULO circulated a letter demanding that Islamic and Arab states not sell their petroleum to Thailand and raising concerns over financial support provided to Thailand by some OIC member states.

In 1975, National Liberation Front of Patani (NLFP) submitted a letter to the OICôs General Secretariat seeking weaponry supports and requesting the establishment of an office in the OICôs member states to perform its mission in those countries. Moreover, the NLFP

\footnotetext{
${ }^{92}$ Dr. Jaran Maluleem, The OIC and the problem of Muslim minority in the Deep South of Thailand, (OIC kub Panha Khong Chon Klum Noi Muslim nai Phak Tai Tonlang khong Thai) an article from Deep South Watch Group. Accessed on March 2012. www.deepsouthwatch.org/node/1281
} 
demanded that the OIC establish a fact-finding committee to oversee the Muslim situation in the southern provinces of Thailand.

In 1988, PULO demanded of the Jordanian government, as chair of the Council of Foreign Ministers (CFM) meeting, the second most important organ of the OIC after the Summit, to participate in the conference for better opportunities to present the case of Southern Thai Muslims to the members of the OIC. Eventually, the demand was rejected by the Jordanian Government. ${ }^{93}$

Many attempts followed after the year 1988 till 1995 but none of these were successful. The separatistsô demands were mainly opposed by some influential member states in the OIC such as Malaysia, Indonesia and Pakistan and some countries in the Middle East region.

However, in 1996 a committee called the Government Expert on Fundamental Rights of Muslim Minorities and Muslim Communities in Non-OIC Member States was formed. The Committee seriously discussed a report regarding the situation of the Muslim Minority in the southern provinces of Thailand. The meeting discussed the separatist movementsôdemands, after many repeated attempts were carried out by the groups. The meeting concluded by suggesting that the Thai authority and the separatist groups should end the conflict in the south by peaceful dialogue. As stated earlier, the OIC had, at the time, an experience with the same pattern of conflict in southern Philippines and it succeeded, to some extent, in convincing both the Government of the Philippines and the separatist groups to sit at a negotiating table. From this point onward, the OIC considered the case of the Philippines as its best practice and applied the lessons that could be drawn from that. The OIC therefore had a very strong intention to apply the same policy to the problem in the South of Thailand. In the same connection, the Committee suggested that the case of Muslim minority in the south of Thailand should be presented to the CFMôs meeting to be convened in Jakarta, at the end of 1996. To prevent the issue being discussed in the CFMôs meeting which would possibly lead to the adoption of a critical resolution affecting negatively on the image of the Thai government on the way it handled and treated the Muslim minority, the Thai government had no other choice than to lobby some OIC member states using its friendly diplomatic relations with those countries to undermine and block the separatistôs efforts through the OICôs secretariat. $^{94}$

${ }^{93}$ Ibid. http://www.deepsouthwatch.org/node/1281
${ }^{94}$ Ibid. http://www.deepsouthwatch.org/node/1281 
During preparation for the $10^{\text {th }}$ OIC Summit, scheduled to held in Putrajaya, Malaysia, representatives from separatist groups attempted to register their names as participants to the Summit under the name of Thailandôs delegation but such tricky attempts were blocked by both Thailand and the host country, Malaysia. Interestingly, the Muslim minority in the south of Thailand tended to be allied with Malaysia in terms of religion, culture and ethnic background but as a sovereign state Malaysia did whatever it could to prevent its relations with Thailand from being ruined by outside factors, even though, Malaysian authorities and its majority people seemed sympathetic with the Muslim minority in Southern Thailand.

In 2003, during the CFM meeting in Istanbul, Turkey, some leaflets were circulated to participants by the PULO Information Bureau in Europe. The information in the leaflets, of course, was not in Thailandôs favour. They alleged that the Muslim minority in the south of Thailand was badly treated. ${ }^{95}$

Then most recently, from 2003 to 2010 , there were no further attempts, whether in the form of participating in meetings or secretly distributing leaflets to participants, even though according to security information there were very active movements especially before every CFM meeting, seeking to persuade the OIC to accept a representative from the separatist movements but these attempts were always rejected by some member states and the host country.

\section{Thailand and Observer Status of the OIC}

Thailand $\hat{Q}$ approach to gain observer status began in earnest during the time that the Ministry of Foreign Affairs was under the administration of Dr. Surin Pitsuwan. ${ }^{96}$ During the time of his administration, the Ministry of Foreign Affairs of Thailand had a policy of greater engagement with Islamic states. Thailand therefore submitted its application to the OIC and was accepted in 1998 with support from its allies within the $\mathrm{OIC}^{97}$. The idea of gaining observer status has proved to be a successful approach for the Thai authority. In the time of peaceful atmosphere the OIC was considered as a forum for Thailand to gain a greater cooperation with the Islamic world while in times of conflict the OIC could also be considered as a framework to defend itself against unwanted rivals.

\footnotetext{
95 Ibid. http://www.deepsouthwatch.org/node/1281

${ }^{96}$ Dr. Surin Pitsuwan is the current ASEAN Secretary General. Dr. Pitsuwan is a Muslim from upper south of Thailand who served as Foreign Minister of Thailand from 1997-2001. Source: Duncan McCargo, Rethinking Thailandôs Southern Violence. NUS Press 2007. 115

${ }^{97}$ Official website of the Ministry of Foreign Affairs of Thailand. www.mfa.go.th
} 


\section{The Secretary General and the Southern Unrest}

The current Secretary General of the OIC, Professor Ekmelleddin Ihsanoglu, assumed the position of the $9^{\text {th }}$ Secretary General in 2005. A very well-known academic within the Islamic world, Professor Ihsanoglu was the first Secretary General to be democratically elected by the OICôs member states since the establishment of the $\mathrm{OIC}^{98}$. It is coincidental that the current wave of the conflict in the south of Thailand has occurred during the time that the OIC was undertaking many reforms within its organization. One of the most interesting agendas that caught the attention of the OIC was the issue of Muslim minorities and Muslim communities in non-member states. The first engagement of the OIC with the Thai authorities after Prof. Ihsanoglu taking office as Secretary General followed in the wake of the Tak Bai tragedy in 2004.

\section{Tak Bai Incident}

The Tak Bai ${ }^{99}$ incident led to the death of 85 local Muslims. It is one of the most tragic incidents in the current wave of unrest ${ }^{100}$. On 25 October 2004, Muslim villagers gathered in the front of the Tak Bai Police Station to demonstrate for the release of 6 men who were alleged to have provided weapons to militants and were detained by police at Tak Bai Police Station $^{101}$. The encounter between thousands of protesters and the Tak Bai police officers brought the situation to a peak of tension when protesters attempted to break through the police security barricades. In order to strengthen security, armed forces were called in to support the police in controlling the on-going escalation. The security forces used water, tear gas and lethal weapons to stop the protesters from breaking through the barricade. During the chaotic situation, many shots were heard. As a result, 7 protesters were killed on the spot by mysterious bullets and 1,298 were arrested. The armed forces who controlled the situation forced all those who were arrested to lie face down on the ground with their hands tied behind. All of the detainees were transported to Inkayuth Army Camp in Pattani Province which was 120 K.M. from Tak Bai district. The detainees were badly treated by the armed forces which loaded them onto 6 wheeled trucks, with 5 or 6 layers of arm-tied detainees on

\footnotetext{
${ }^{98}$ See the official website of the OIC: www.oic-oci.org

${ }^{99}$ Tak Bai is a district located in Narathiwat province which one of three provinces of southernmost of Thailand

${ }^{100}$ See details on Takbai Incident from the report of Amnesty International, 24 October 2006.

http://www.amnesty.org/en/library/asset/ASA39/015/2006/en/ddd8d982-f9d1-11dd-b1b0c961f7df9c35/asa390152006en.pdf

${ }^{101}$ Max L. Gross, A Muslim Archipelago: Islam and Politics in Southeast Asia.79
} 
top of each other, resulting in 78 deaths during transportation due to suffocation and physical mal-treatment by the armed forces. ${ }^{102}$

This tragedy caused frustration amongst Muslim people in the south due to the loss of lives of many Muslims due to callous mishandling of detainees. It is thought that not all detainees were protestors. Some of them were present at the scene only because of their curiosity. The tragedy was even worse because it occurred during the holy month of Muslims, the month of Ramadan. ${ }^{103}$ As a result, it fuelled the already worsening situation to become deeper and more related to the religious dimension, overwhelming with their fellow Muslims in conflict area.

The Tak Bai incident caught the attention of many Muslims from inside Thailand as well as outside. The OIC, of course, condemned the Thai authorities for mishandling the situation and ill-treating the detainees. The OIC condemned the tragedy and called the Thai authorities to seriously investigate the tragedy and consider appropriate measures for punishing those responsible. ${ }^{104}$

Since then, the current chapter of relations between Thailand and the OIC, on the southern conflict, began. The Thai authorities, of course, responded to that condemnation by dispatching a special envoy led by an advisor to the Foreign Minister, Dr Nissai Vejjajiva to meet the Secretary General of the $\mathrm{OIC}^{105}$. The visit was aimed at providing first-hand information on the Tak Bai incident. The meeting concluded by the expression of the OICôs satisfaction after it was acknowledged that the Thai authorities had established an independent committee, called ñThe Independent Investigation Commissionò to further investigate the incident in particular and the whole southern conflict in general, as well as to provide suggestions and advice to the Thai government towards sustainable peace in the region. The OIC expressed its readiness to coordinate with the Thai government in providing necessary support in resolving the conflict. There were several important points on which the Secretary General expressed his concern but in general he stressed that the Thai government should guarantee the rights of the Muslim minority in the country, especially in the southernmost regions, the government must treat Muslims as equals of the majority

\footnotetext{
${ }^{102}$ Peter Chalk, The Malay-Muslim Insurgency in Southern Thailand: Understanding the Conflictô Evolving Dynamic, National Defense Research Institute, 2008. 19

${ }^{103}$ Ramadan is the $9^{\text {th }}$ month according to Islamic lunar calendar. It is considered one of the holiest months for Muslims. It is the month when Muslims fast from dawn till dusk.

104 ñCrisis in South: OIC seeks safety for Muslimsò, Nation Multi Media, accessed on May 2012. http://nationmultimedia.com/2007/05/01/national/national_30033083.php

${ }^{105}$ Official Website of the Ministry of Foreign Affairs of Thailand, http://www.mfa.go.th/web/463.php?id=3410\&lang=th
} 
population in the country. In the other hand, the Secretary General attached the importance of peaceful dialogue between the Thai authorities and Muslim separatist groups. The Secretary General also reassured that the sovereignty, dignity and integrity of Thailand must be respected.

It is in no doubt that both the Thai authorities and the OIC are currently working for the same goal: a sustainable peace in the region. It is also apparent that to the Thai government the unrest in the southern provinces is considered as a political stalemate as well as a security dilemma that stand as a blockage in the middle of the road leading to social, political and economic development of the region. A sustainable peace in the region therefore is at stake for the Thai government. On the other hand, the peace that has long been sought is also at stake for the OIC for the betterment of the Muslim minority in the country. It is agreeable, then, that a just solution and a peace settlement in the region is a common and mutual interest of both the Thai government and the OIC. In spite of this, relations between both sides seem contentious. It is therefore, quite useful to examine points of different between both sides.

\section{The OIC views of the unrest in Thailand}

The OIC involvement in the conflict in southern Thailand has not happened without difficulties. From a first glance, relations between Thailand and the OIC should get through without any problem but the reality on the ground proves otherwise. Thai authorities, during the period, have seen the OICôs intervention in the conflict as beyond its mandate. On the other hand, the OIC perceives that what the Thai authorities have done has not been to the benefit of the Muslim minorities and a very little progress has been done in upholding the rights of Muslim minority in the country and there are many avenues for action towards a peaceful solution to the conflict.

As stated earlier, the OIC views the intervention in southern Thailand as its necessary mandate for the following reasons:

- It is of the OICôs obligation to uphold Muslim minorities and safeguard their rights in non-Islamic states. These are issues that cross over territorial boundaries. The main mission of the OIC is to uphold universal rights with religious bonds. The OIC therefore always calls the Thai authorities to guarantee the rights of the Muslim minority in the country. 
- The OIC strongly views that the conflict in southern Thailand cannot be solved unilaterally by the Thai authorities without participation from the Muslim minority and the mediation of the OIC. The Thai authoritiesôviews have been different on this point. Until recently, the unrest in the region is still blurred. Despite the scale of insurgency and frequent occurrence of attacks, no groups have claimed responsibility, ever since. Furthermore, insurgency groups who were believed to be responsible for the unrest showed no sign of readiness to settle the conflict by initiating a peace dialogue directly with the Thai authorities. The insurgency groups seemed somewhat radical in their stance toward this. The OIC therefore believes that the conflict could only be eliminated if both the Thai government and representatives of the Muslim minority sit together at negotiating table. ${ }^{106}$

In this regards, the Thai government seems different in its view for the following reasons:

- According to Thai government, the conflict in the south of Thailand is merely an internal affair and therefore should be solved as the Thai authorities deem appropriate. The OIC approach might not satisfy the Thai authorities that the OIC would not be biased in its position toward the conflict. In addition, the past record of the OIC as well as its secret contacts with some separatist groups might cause the Thai authorities to doubt the OICôs role in the conflict.

- In regards to negotiation, always highly emphasized by the OIC, there is a relatively wide gap in the views of both parties. While the OIC attaches importance to peaceful dialogue towards a sustainable peace solution to the conflict, the Thai authorities see otherwise. While the OIC sees the struggle in the south as the reaction of Muslim minorities to protect their rights, the Thai authorities see the said activities as something endangering to the peace and stability of the country and its people and depict those who carried out such activities as culprits. The Thai authorities see that by sitting at a negotiating table with culprits, as depicted by the authorities, who carried out criminal offences against innocent people will definitely legitimize those culprits and what they have done. It is therefore quite difficult for both parties to meet together at the same point.

106 ñOIC Calls for Dialogue to Solve Thailandôs Southern Conflictò, New Straits Times, Accessed on May 2012. http://www.nst.com.my/latest/oic-calls-for-dialogue-to-solve-thailand-s-southern-conflict-1.82855 
To get a clearer picture we should consider that there have been three parties involved in this disagreement. The Thai authority on one hand, the OIC, through its secretariat in the other and thirdly, the member states in the OIC. The OICôs reaction regarding the southern conflict always comes from the secretariat of the OIC in the form of a press release issued by the Secretary General. In some cases, it comes as a report from the inter-governmental expert committee about Muslim minoritiesô rights or another special committee set up by the Secretary General. Once the processes pass through the Secretariatôs office it then will be presented to the conference of the Ministerial Council of Foreign Ministers for consideration.

The Thai government seems to be successful in responding to the OICôs concerns. As stated earlier, even though the OIC is considered to be a transnational organization, it is, of course, not a supra-organization that can exercise its power without the consent of its member states. Over the time, the voice of the OIC, especially the condemnatory ones, over the conflict in the south of Thailand seems very strong and somewhat aggressive, to some extent. But that strong voice gradually weakened when the issues were being handled by sovereign states within the OIC. The Thai authorities highly depend on their soft power diplomacy with its close partners in the OIC to block any attempts from the OICô Secretariat to treat the issue of the Southern conflict in a way that could harm the image of Thailand on how it treats Muslim minorities in the country.

From the above, it could be said that the main problem for the OIC is its attempt to carry out its proclaimed mission to protect and uphold the rights of the Muslim minority in southern Thailand for the sake of the Muslim Ummah on the one hand, and to respect the sovereignty of Thailand, in the other hand. Although the OIC is a representative of sovereign states, the way it works, sometimes, has no direct relation with the states. While the OIC, through its

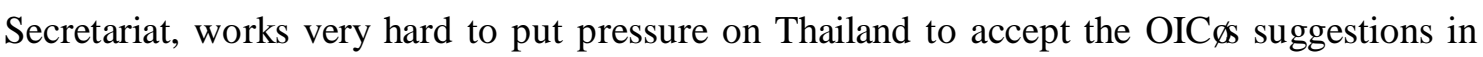
resolving the conflict, the Thai authorities rely on its allies, sovereign states, in the OIC to defend what the Thai authorities sees as right.

Given the previous record of the OIC in its dealing with the insurgency groups this has no doubt led to the Thai authoritiesôcuriosity of what was the real intention of the OIC behind what it has done, along the time. Despite the OICôs charter stating that the OIC attaches importance to state sovereignty, the OICôs activities have showed that the organization has been supporting, and still supports, the Muslim minority in the southern Thailand to secede from Thailand. On many occasions the Thai government has, through official and unofficial 
statements affirmed that there is no minority in the country because the government treats all Thais equally. This could be evident from the Thai constitution, which does not state clearly that Thailand is a Buddhist country, as an indication that all Thais are equal. Unlike some Islamic countries that state in their constitutions that the countries are based on religion, as a principle that must not to be neglected.

Interestingly, while the OIC confidently announced that its intervention in the southern Thailand conflict is merely to uphold the rights of its people in accordance with international norms related to that matter and to protect the universal rights in the name of the global Ummah, the Thai authority viewed such intervention as interfering in its internal affairs and providing a platform for separatist groups to launch political activities to secede from Thailand and form their own state based on religion. Moreover, the Thai authorities, in the same period, have criticized the OICôs stance toward what was going on in the region. The OIC always showed its sympathy with the loss of lives of Muslims even though the victims of the conflicts are not Muslims alone but believers of other faiths as well. More ironically, it is very seldom that the OIC issued any press release condemning acts of terrorism that targeted innocent people. The OIC expressed concern over attacks that took place against Masjid (Mosque) but showed no such sentiment if the attacks were directed against Buddhist temples or monks.

\section{What are the concerns of the Thai Authorities?}

- From the $35^{\text {th }}$ CFM meeting until the latest CFM, the $38^{\text {th }}$ which was held in Astana, Kazakhstan, the OIC Secretariat attempted to issue a country-specific resolution by presenting the issue to the meeting to be considered. Thai government opposes the issuance of a country-specific resolution. The resolution, according to the Thai government, would indicate that the conflict is beyond the control of the Thai authority. More importantly, the resolution will indirectly open a gate more widely to the interference of outside elements be they countries or organizations. If the issue is internationalised, the Thai authority may lose control of the issue and in the worst case scenario, which is quite unlikely to happen, the issue of self-determination of the southern people will be widely debated in the world society, especially among the Islamic states.

- The most prevailing reasons for the Thai authorityố disagreement over the adoption of the resolution were that it could be manipulated by separatist groups to gain 
political ends. The issue has some sensitivity for the Thai government. Moreover, the public awareness of the Thai people, in general, still depicts that the unrest in the region is being carried out by separatist groups and very much related to separatist elements. If the overall Thai society does not accept the idea of autonomy, which is taught to be supported by the OIC, whatever form it may take, any attempt to secede from its main land will, of course, be a most sensitive issue for the Thai public ${ }^{107}$.

- Until recently, the OIC seems to have been resolute. The OIC gives its signal to the Thai government which implies that the one solution to bring about the sustainable peace is dialogue both between the Thai government and the OIC, on one hand, and between the OIC and representatives of the Muslim community of southern Thailand, on the other hand.

To prevent the adoption of a country-specific resolution, the Thai government did not have ample room to move. As stated earlier, there are three actors in the scene. The Thai authority, the member states in the OIC and the OIC itself. Attempts to submit the resolution were made by the OIC to member states in order to adopt the resolution during the CFM meeting, which is held annually. The main difficulties for the Thai authority constituted many forms. As an observer state, Thailand is invited to participate only in the opening and closing ceremonies of the conference, while a critical moment for Thailand during the meeting of Intergovernmental Group of Expert (IGE) on specific issues which is normally held at the OIC Secretariatôs office in Jeddah, Saudi Arabia, prior to the CFM meeting. Suggestions and recommendations from the IGE will be presented to the Secretary General in order to include it in the agenda and to present to the CFM meeting for adoption. From the beginning, through to the process of adoption, the Thai authorities had little chance to defend themselves or, at least, to sit and discuss the possibilities of solution that might suit every party.

The only way for the Thai government to exercise what it sees as appropriate is to discuss the matter directly with member states within the OIC who are close friends of Thailand such as Malaysia, Indonesia, Brunei Darussalam and Bahrain. By cooperating with its close allies, Thailand succeeded in blocking the Secretariatôs attempts to adapt the resolution. Thailand stressed on many occasions that the adoption of the resolution would harm the governmentôs intention to resolve the problem. It would, therefore, be of no benefit neither to the OIC, nor to the Muslim community in the region.

${ }^{107}$ Moshe Yegar, Between Integration and Secession: The Muslim Communities of the Southern Philippines, Southern Thailand, and Western Burma/Myanmar, 2002, p 387 
Thailand is known as one of the countries that has a policy to engage with the international community within and outside of its own region. The use of soft power diplomacy seems to benefit Thailand in various ways. Thailand has very good relations with some ASEAN countries like Malaysia, Indonesia and Brunei Darussalam.

From close examination of the relationship between Thailand and the OIC, in regard to the tension that operates between state sovereignty and a transnational organization the following lesson could be drawn.

It is quite obvious that in the context of international relations state sovereignty, to some extent, still triumphs over non-state actors. In the light of modern world, non-state actors such as trans-national organizations may have some influence over statesô decisions and have some power to put pressure on other states and thus affect the way states act but that has not been seen to be totally true. This is clearer in the case of an organization that is characterised as an inter-governmental organization like the OIC. As long as the state is involved in the organization, whether its involvement is in the form of financial support or any other form of support, the state will prioritise its own interests over those of the organization that it belongs to.

In terms of the OIC, it is quite agreeable that the organization is still dependent on the support of its member states. Any decision that might have an effect on the statesô sovereignty is more likely to be addressed in very discrete ways. As we could witness in the case of Thailand, in terms of the conflict in the south, which is related to the Muslim community in the country, some member states in the OIC are, somewhat, taking a direction in opposition to the General Secretariatô intentions. While the Secretariat possesses a very strong stance and seems aggressive in addressing the southern conflict by approaching the Thai authority and showing its readiness to be a mediator for the dialogue between the Thai authority and the Muslim community, (which is strongly opposed by the Thai authority), the said activities are perceived by the Thai authority as interference in its internal affairs and obviously support and encourage the Muslim community to stand against the government. Thailand therefore has no other way to protect its sovereignty but to exercise its diplomacy by seeking the cooperation of its close allies. Since Thailand and some OIC member states such as Indonesia, Brunei Darussalam and Malaysia ${ }^{108}$, in the context of the primary members of

${ }^{108}$ Dr. Imtiyaz Yusuf, the Southern Thailand Conflict and the Muslim World, a research project presented to a Public Seminar on ñSouthern Violence and the Thai State: Non Violence, Violence, and Thai Societyò, Senior 
regional partnership, ASEAN, as well as some Islamic states in the Middle East such as the Gulf Cooperation Countries (GCC) like the Kingdom of Bahrain, Qatar, the UAE and other countries such as Egypt, Jordan and Morocco, all have very strong ties with Thailand in terms of economic, social and political relationships ${ }^{109}$.

However, the positive cooperation that the Thai authority enjoys from its close allies does not mean that those countries are against the OICôs principle of upholding the rights of the Muslim minorities in the south of Thailand. It is undoubted that those countries attach a great importance to safeguarding, protecting, promoting and upholding the rights of the Muslim minorities since those rights are considered to be universal values that must be guaranteed, let alone the religious bond that is beyond everything else. But what might have diverted the stance of those countries was surely constituted in their deep political points of view. Some states may perceive that state-to-state cooperation would benefit the Muslim community in the conflicted area. This could be evident from various cooperative actions between Thailand, particularly some civil society bodies such as educational institutions, and some Middle East governments currently being pursued. These kinds of cooperation might indirectly raise the living standards of Muslims in the region and thus create more positive opportunities to be good citizens rather than being depicted as an obstacle to overall development.

Despite of the relative lack of success by the OIC in projecting its power to intervene in the southern Thai conflict the OIC will maintain its stance toward the southern Thai conflict as it did in the past for several reasons:

- The current contact between the OIC General Secretariat and some separatist groups will continue to give impetus to the OIC to proceed with what it deems necessary for them to gain certain political goals due to the fact that the information from the separatist group handed to the OIC is definitely not in the favour of Thailand. Besides, the secret contact between both entities is perceived by the Thai authority as something unusual and represents hidden agendas which imply some wrong intentions behind the OICôs attempts to intervene in the conflict. This circumstance is considered to be a political obstacle to the relations between the OIC General

Research Scholar, the Thailand Research Fund (TRF) in Cooperation with Princes Maha Chakri Sirindhon Anthropology Centre and the Faculty of Political Science, Thamasat University, August 2006. P 21

${ }^{109}$ ñBahrain to Help Thailand Inform OIC of Deep South Factsò, MCOT News, http://enews.mcot.net/view.php?id=2467 
Secretariat and The Thai government through the period, which led, of course, to mistrust between both parties, affecting negatively attempts to resolve the conflict.

- According to the OIC, there is no remarkable progress in the situation in the south of Thailand. The unrest is still occurring on an almost daily basis. The Thai authorities still prioritise security measures by deploying a massive number of military personnel, ignoring other important issues such as guarantee a just solution to Muslims, eradicating social impairment and promoting economic for the betterment of Muslims ${ }^{110}$. Once the OIC perceives the situation in the south as it was mentioned earlier, it will continue to gain support from member states to put more pressure on Thailand to carry out what the OIC deems useful to the Muslim community in the south.

From the above passage it could be summarized that the OICôs involvement in the Southern conflict is based on the following significant reasons.

- Upholding the universal value of human rights in the name of the global Ummah The OICôs adoption of the Cairo Declaration on Human Rights in Islam during the Conference of Ministerial Meeting in Cairo in 1990 was significant evidence that the OIC attaches importance to human rights within an Islamic concept. As Abul Alaô Maududi (1903-1979), one of the most prominent religious ideological thinkers in Islam would argue that the principle of human rights in Islam cannot be separated from Islamic Law, Shariah ${ }^{111}$. The concept of Ummah which is considered to be the most prevailing element in the Islamic understanding tends to be sufficient for the OIC in carrying out its mission. The OICôs mission toward this is a combination of promoting universal values and upholding the concept of a global Islamic Ummah. As the annex of the Cairo Declaration, as its principle, says né Believing that fundamental rights and universal freedoms in Islam are an integral part of the Islamic religionò ${ }^{112}$ It is therefore very obvious that the principle of the OIC in terms of upholding the universal rights of Muslim minorities is related to religious concepts. It is the concept that could not be divided. The Declaration stressed at the end that the ñIslamic Shari'ah (Islamic Law) is the only source of reference for the explanation or

\footnotetext{
${ }^{110}$ Dr. Imtiyaz Yusuf, the Southern Thailand Conflict and the Muslim World, a research project presented to a Public Seminar on ñSouthern Violence and the Thai State: Non Violence, Violence, and Thai Society, p 20 ${ }^{111}$ Abul AlaôMaududi, Human Rights in Islam, Islamic Publication Ltd., Lahore, $2^{\text {nd }}$ Edition, 1995. p 12

112 The Cairo Declaration of Human Right in Islam. The official website of the OIC http://www.oic-oci.org/english/article/human.htm
} 
clarification of any of the articles of this Declarationò. On top of that, it could be argued that the OICôs intervention is derived from the ethical sense of responsibility. This empowers the force to proceed with interventions against a passive movement by some states or another entity.

- On the other hand, the involvement of the OIC in the southern conflict tends to be related to the engagement to which the Thai authority is committed as an observer state in the OIC. By stepping into the OIC forum, Thailand has to weigh between enjoying other benefits such as gaining political negotiating power from, or having trade opportunities with, its allies within the OICôs framework, and giving away some aspects of its sovereignty over its own internal affairs. As the OIC would depict that gaining the observer status will only benefit Thailand in terms of raising the living standards of the Muslim minority in the country while Thailand deemed the accession to the OIC as providing several benefits, including, giving the opportunities to Thailand to engage itself in a closer manner to its allies, sovereign states. Beside, to be in the inner circle of the OIC will, to some extent, allow Thailand to monitor in a closer way all suspicious movements and contacts between separatist group and the OIC Secretariat.

To sum up, it is quite clear that the OICôs mandate was to protect the human rights of the Muslim minority in the south of Thailand. To this end, the OIC as a representative of sovereign states is officially authorized by member states to intervene in the name of the OIC. The mandate is undoubtedly considered as a great mission that should be praised since human rights is one of the most important universal values that people uphold but the enforcement and protection of human rights has been difficult because of the tension between universal values and state sovereignty. Although the OIC, as a transnational organization, is a representative of its sovereign members, the statesôinterests were considered as hindrance in the way of the OIC preventing the OIC from exercising its power to the success of its mission. In terms of this, it could be evident that no matter how important the universal value is, the enforcement in maintaining the said value must not ignore the role of sovereign states. The OIC is a representative of sovereign states; to perform its mission the OIC could not further its mission, at some state, without the consent or permission of its member states. The OIC therefore, possess great limitations in fulfilling its proposed targets. In terms of Thailand, the Thai authorities, along the time, succeeded in maintaining its friendly relationship by conducting soft power diplomacy. Thailand seems successful in turning some 
influential countries within the OIC from criticizing, to the countries that speak for the favour of Thailand.

The good cooperation between Thailand and its allies could be evident from the various productive programmes in different fields of interest. Recently, countries like Qatar, UAE, Kuwait, Saudi Arabia and Egypt contributed financial support as well as scholarships to promote education in the southernmost provinces of Thailand ${ }^{113}$. Many positive projects, with cooperation from the Thai government and Muslim scholars in the region, have recently been launched. The most recent project is the establishment of a local charitable hospital. ${ }^{114}$ To the Thai authorities, it is of benefit to the Muslims in the region to gain positive and productive support from its allies from different parts of the world. Such development projects are of vital importance to the Muslims in the south of Thailand and may play a very vital role in achieving sustainable peace in the region. This could also indicate that the Thai authorities and its allies agree, to some extent, that a mere political solution will not lead to a positive development in the conflicted area but cooperation for the betterment of the Muslim people in the region in all aspects must also be brought to the attention of all parties involved.

\footnotetext{
${ }^{113}$ ñKuwait Awqaf official breaks ground for info center at Yala Islamic univò. Kuwait News Agency, http://www.kuna.net.kw/ArticleDetails.aspx?id=2145441\&language=en

114 ñLaying of Foundation Stone of Sheikh Jassim bin Mohamed Hospital in Thailandò. Official Website of the Embassy of Qatar in Bangkok. http://www.qatarembassy.or.th/news/news_0027.html
} 


\section{Conclusions}

From the above I conclude as follows:

1. In terms of the protection of human rights in the context of Western and NonWestern organizations, there are similarities and differences that could be noted.

a. Similarities

Sovereign states are always concerned about outside intervention in their internal affairs and are worried about setting precedents for intervention in their own activities. Furthermore, there are difficult ethical and political questions related to the upholding of human rights both in the context of the Western and NonWestern countries. It is in no doubt that states have most power and it may be more sensible to work with them rather than against them.

b. Differences

In the context of the Islamic world, the protection of human rights seems to be the same whether it is within Islamic states or non-Islamic states. This, to some extent, contrasts with some perceptions that the West enforcement of human rights is mostly concentrated on Non-Western states rather than issues within their own territory.

On the other hand, it is undoubted that while the promotion of human rights is important for the betterment of humankind, issues of neutrality in attempts to uphold the said human rights must also be addressed. Within the concept of Islamic Ummah, the issue of neutrality is vulnerable to criticism by Non-Islamic countries. While the OIC claims its mission is to protect the human rights of Muslims specifically, that seems to weaken its claim to neutrality.

2. As a representative of 57 Islamic states, the $\mathrm{OIC}$ tends to be the largest religious related organization with a political motivation. The OIC involvement in nonIslamic states is through the belief in a moral mandate to protect human rights in the name of the Islamic Ummah in countries that host Muslim minorities and communities, throughout the world.

3. The OIC involvement with regards to the protection of human rights in nonIslamic states is extremely challenging. In fact, the OIC was established by sovereign states, its Charter therefore was not based merely on religious understandings; it is also very much relies on the universal understanding of state sovereignty. The OIC therefore, while working for the cause of the global 
Ummah, with a religious motivation, is also very conscious in dealing with sovereign states in order to respect the statesôdignity, integrity and sovereignty.

4. Inevitably, contention between protecting the rights of Muslim minorities and how to respect statesôsovereignty has arisen. This kind of problem will not be widely debated if the involvement of the OIC is happening within the boundaries of its member states, the issue will be caught in the middle of controversy if the involvement is occurring in non-member states or non-Islamic states. It is, perhaps, the grey area between the protection of human rights and the support for the cause of Muslim minorities to the extent of proclaiming their rights to selfdetermination is one of the strongest obstacles for the OIC in working towards fulfilling its missions in non-member states. Non-Islamic states may perceive the involvement of the OIC as encouragement for Muslim minorities to rebel against their own nations. Such sentiments are definitely not welcomed by any state that hosts a Muslim minority.

5. The conflict in the southern provinces of Thailand and the OIC involvement in the conflict, exemplifies the extent of tension between protecting the rights of Muslim minorities and respecting the sovereignty of the state. While the OIC carries out its mission in protecting the rights of the Muslim minority in Thailand, it seems that the OIC faces some limitations with regards to the sovereignty of Thailand. In response to the OIC intervention, Thailand relies on its fellow sovereign states within the OIC to defend what it believes necessary. The success of Thailand in applying its soft power diplomacy with its allies in the OIC is considered to be a proof that sovereign states are always in the same position when they deal with issues of mutual interest. As interference in other statesô affairs is a relatively sensitive issue to sovereign states, Thailand would consider dealing with its allies, sovereign states, is better for Thailand and its Muslim population in the south. The OIC succeed in upholding the rights of Muslim minority in the south of Thailand if it concentrated more on positive relations through its member states that are close to Thailand rather than exercising its power, which is seen as aggressive, to some extent.

6. The OIC should make itself clear, without any hesitation, that its intervention in the southern Thailand conflict is merely for the cause of upholding Muslim minoritiesô rights and shows its readiness in supporting Thai authorities in its effort in resolving the conflict in a very positive manner rather than acting as a 
monitoring body exercising its power over a sovereign state which occasionally leads to the perception by the Thai authorities that the OIC is supporting the Muslim minority in the country to gain self-determination, which is unacceptable, whatsoever, to the Thai authorities. Once the Thai authorities perceive the work of the OIC in this way, it will give Thailand a very little choice to consider. Thailand will definitely consider every measure it deem necessary to protect its sovereignty, integrity and dignity. Sovereign states therefore are Thailandôs best solution to the problem.

7. The transnational organizations, as non-state actors may have some influence on sovereign statesôdecision, but this influence does not totally eradicate the role of sovereign states in shaping the statesôpolicies. The religious dimension combined with universal nature of understanding in the case of the OIC and its mission in protecting the Muslim minoritiesôrights could narrow down the scope of the OIC and helping it to concentrate on the cause of the Muslim minorities in particular. It is not guaranteed that the OIC could carry out its mission without any hindrance. Being a representative of 57 countries, the OIC must work in the same rhythm with its sovereign member states. Any disagreement will cause the work of the OIC to fail or stagnate.

8. To gain the goal of protecting of the rights of Muslim minorities there must be strong state-to-state cooperation. Through the cooperation from the same criteria of entities, the issues will be easily discussed. At the very least, a state that hosts a Muslim minority will rest assured that the intervention into its local affairs is merely for betterment of its Muslim people in the country without touching negatively on the issue of state dignity, integrity and sovereignty. Being criticized for the inappropriate treatment of its own people by close allies is less indicative than the sovereignty of the state is being endangered or threatened. It is in no doubt that state sovereignty still triumphs over external factors that could only be additional elements that with it alone is less likely to cause any remarkable success. 


\section{Bibliography}

Abhyankar, Rajendra, Madhukar. West India and The Region: Defining Indiaô Role, New Delhi, India, 2008.

Abuza, Zachary. Conspiracy of Silence, The insurgency in Southern Thailand. United State Institute of Peace

Ahsan, Abdullah. Ummah or Nation? Identity Crisis in Muslim, Leicester: Islamic Foundation, 1992

Akbarzadeh, Shahram., and Yasmeen, Samina. Islam and the West: Reflection from Australia, University of New South Wales Press, 2005

Akram, Ejaz. Muslim Ummah and its Link with Transnational Muslim Politics

Amer, Ramses and Zou, Keyuan. Conflict Management and Dispute Settlement in East Asia, 2011

Anderson, Robert. National Identity and Independence Attitudes: Minority Nationalism in Scotland and Wales. Centre for Research into Elections and Social Trends, working paper No. 86, September 2001

Aphonsuva, Thanet. History and Politics of the Muslims in Thailand, Thamasat University, Bangkok, 2003

Aree, Sarawut. Chulalongkorn University, Bangkok. ñNayobai OIC Tor Panha Chon Klum Noi”: (OICố Policy towards Minorities).

Bajoria, Jayshree and Zissis, Carin. ñThe Muslim Insurgency in Southern Thailandò, Council on Foreign Relation, September 10, 2008

Bhandari, Mohan C. Solving Khasmir, India 2006.

Brown, A.C. Jonathan. Hadith, Oxford University Press, 2010

Chalk, Peter. Malay-Muslim Insurgency in Southern Thailand: Understanding the Conflictô Evolving Dynamic, National Defense Research Institute, 2008

Chavez, Edgar et al. Mindanao: Understanding Conflict 2011, Conflict Management Program, Student Field Trip to Mindanao, John Hopkins University, School of Advanced International Studies

Che man, WK. Muslim Separatism: The Moros of Southern Philippines and the Malays of Southern Thailandò. Oxford University Press 1990

David Jr, Ricardo A. The Causes and Prospect of the Southern Philippines Secessionist Movement. Naval Post Graduate School, Monterey, California. December 2003.

Denny M, Frederick. Ummah in the Constitution of Medina, Journal of Near Eastern Studies, Vo. 36. No. 1 (Jan. 1977)

Denny, Frederick M. The Meaning of Ummah in the Quran, History of Religion 15 (1975): 3470, University of Virginia

Esposito L. John. Islam and Politics, Syracuse, New York, 1984

Farouk, Omar. ñThe Historical and Transnational Dimensions of Malay-Muslim Separatism in Southern Thailandò. Armed Separatism in Southeast Asia, edited by Lim Joo-Jock and Vani S. 
Gabriele, Marranci. The Anthropology of Islam. Oxford: Berg, 2008

Gross, Max L. A Muslim Archipelago: Islam and Politics in Southeast Asia, Government Printing Office, 2007.

Gunn, Geoffrey C. History Without Borders: the Making of an Asian World Region, 1000-1800, The Patani Sultanate: Facing down Siam, Hong Kong University Press, 2011

Harders, Ciljar., and Legrenzi, Metteo. Regionalism? Regional Cooperation, Regionalism and Regionalization in the Middle East. Ashgate, England, 2008

Harish, S. P. Changing Conflict Identities: The Case of the Southern Thailand Discord, Institute of Defense and Strategic Studies, Singapore, February 2006

Harish, SP. Ethnic or Religious Cleavage? Investigating the Nature of the Conflict in Southern Thailand. Contemporary Southeast Asia Vol. 28 No. 1(2006)

Haynes, Jeff. Transnational Religious Actors and International Politics, Third World Quarterly, Vol. 22, No. 2 (Apr., 2001)

http://www.oic-oci.org

Ihsanoglu, Ekmeleddin. The Islamic World in the New Century: the Organization of the Islamic Conference, 1969-2009. Hurst, 2009.

John, Wilson. Pakistan: the Struggle Within, India 2009.

Jory, Patrick. Thai South and Malay North: Ethnic Interaction on a Plural Peninsular, National University of Singapore, 2008

Kuwait News Agency. http://www.kuna.net.kw

Legaspi, Edgardo Pedro. Case Study of Ethnic Conflicts in Southern Philippines and Southern Thailandô $6^{\text {th }}$ Asia-Europe Round Table Minority Conflict-Toward an ASEM Framework For Conflict Management

Liow, Joseph Chinyong and Phatan, Don. Confronting Ghosts: Thailand Shapeless Southern Insurgency, The New Insurgency, Lowy Institute for International Policy, 2010, Paper No.30

Maluleem, Jaran. The OIC and the problem of Muslim minority in the Deep South of Thailand, (OIC kub Panha Khong Chon Klum Noi Muslim nai Phak Tai Tonlang khong Thai) an article from Deep South Watch Group.

Maududi, Abul Alaô Human Rights in Islam, Islamic Publication Ltd., Lahore, $2^{\text {nd }}$ Edition, 1995

McCargo, Duncan. Rethinking Thailandôs Southern Violence. NUS Press, 2007

McCargo, Duncan. Duncan McCargo, Tearing Apart the Land: Islam and legitimacy

in Southern Thailand, Cornell University, 2008.

MCOT News, http://enews.mcot.net/view.php?id=2467

Mehden R. von der Fred. Two Worlds of Islam: Interaction Between Southeast Asia and the Middle East, The University Press of Florida, 1993

Melvin, Neil J. Conflict in the Southern Thailand: Islamism, Violence and the State in the Patani Insurgency. SIPRI Policy Paper No. 20 
Montesano, Michael J. and Jory, Patrick. Thai South and Malay North: Ethnic Interaction on a Plural Peninsular, National University of Singapore, 2008,

Muhammadi, Ali. Islam Encountering Globalization, New York, 2002

Nationmultimedia.com

New Straits Times. http://www.nst.com.my

r̃No one is selfò, Human Rights Watch, Volume 19, No. 13

Salmi, Ralph H. et al. Islam and Conflict Resolution: Theories and Practice, University Press of America 1998

Sandra Ruth Leavitt, ñPersuasion, Coercion, and Neglect: Understanding State Policy and the Mobilization of Muslim Minorities in AsiaÒ(PhD Diss., Georgetown University, 2007).

Sardar, Z. Islamic Future. The Shape of Ideas to Come, London, Mansell, 1958

Satha-Anand, Islam and Violence: A case study of Violent Events in the Four Southern Provinces, Thailand

Scholte A Jan. Building Global Democracy?: Civil Society and Accountable Global Governance, Cambridge University Press, 2011

Shaban, M. A. Islamic History: A New Interpretation I A.D. 600 Ï 750 (A.H. 132), Cambridge University Press, 1976

ñSouthern Thailand Insurgency not Jihadò Asia Report No 98 ï 18 May 2005.

International Crisis Group

Storey, Ian. Ethnic Separatism in Southern Thailand: Kingdom Fraying at the Edge? Asia-Pacific Center for Security Studies 2007

Stowe, Judith A. Siam Becomes Thailand: A Story of Intrigue, London, 2008

Tarling, Nicholas. The Cambridge History of Southeast Asia: The Nineteenth and Twentieth Centuries, Cambridge University Press, 1992

Wayne, Bougas. Patani in the Beginning of XVII Century. In: Archipel, Volume 39, 1990

www.mfa.go.th

www.qatarembassy.or.th

Wyatt, David. Thailand: A short History. New Heaven: Yale University Press, 2003

Yegar, Moshe. Between Integration and Secession: The Muslim Communities of the Southern Philippines, Southern Thailand, and Western Burma/Myanmar, 2002

Yusuf, Imtiyaz. The Southern Thailand Conflict and the Muslim World, a research project presented to a Public Seminar on ñSouthern Violence and the Thai State: Non Violence, Violence, and Thai Societyò, Senior Research Scholar, the Thailand Research Fund (TRF) in Cooperation with Princes Maha Chakri Sirindhon Anthropology Centre and the Faculty of Political Science, Thamasat University, August 2006 